\title{
Minerals in the rhizosphere: overlooked mediators of soil nitrogen availability to plants and microbes
}

\author{
Andrea Jilling $(\mathbb{D} \cdot$ Marco Keiluweit - Alexandra R. Contosta $\cdot$ Serita Frey \\ Joshua Schimel 1 Jörg Schnecker • Richard G. Smith • Lisa Tiemann • \\ A. Stuart Grandy
}

Received: 24 September 2017/ Accepted: 16 May 2018/Published online: 7 June 2018

(C) The Author(s) 2018

\begin{abstract}
Despite decades of research progress, ecologists are still debating which pools and fluxes provide nitrogen $(\mathrm{N})$ to plants and soil microbes across different ecosystems. Depolymerization of soil organic $\mathrm{N}$ is recognized as the rate-limiting step in the production of bioavailable $\mathrm{N}$, and it is generally assumed that detrital $\mathrm{N}$ is the main source. However, in many mineral soils, detrital polymers constitute a minor fraction of total soil organic N. The majority of organic $\mathrm{N}$ is associated with clay-sized particles where
\end{abstract}

Responsible Editor: Kate Lajtha

A. Jilling $(\varangle)$

Department of Natural Resources and the Environment,

University of New Hampshire, 114 James Hall, 56

College Road, Durham, NH, USA

e-mail: aj5@wildcats.unh.edu

M. Keiluweit

School of Earth \& Sustainability and Stockbridge School of Agriculture, University of Massachusetts, Amherst, MA, USA

e-mail: keiluweit@umass.edu

\section{A. R. Contosta}

Institute for the Study of Earth, Oceans, and Space, University of New Hampshire, Durham, NH, USA

e-mail: Alix.Contosta@unh.edu

S. Frey · J. Schnecker - R. G. Smith · A. S. Grandy Department of Natural Resources and the Environment, University of New Hampshire, Durham, NH, USA

e-mail: serita.frey@unh.edu physicochemical interactions may limit the accessibility of N-containing compounds. Although mineralassociated organic matter (MAOM) has historically been considered a critical, but relatively passive, reservoir of soil $\mathrm{N}$, a growing body of research now points to the dynamic nature of mineral-organic associations and their potential for destabilization. Here we synthesize evidence from biogeoscience and soil ecology to demonstrate how MAOM is an important, yet overlooked, mediator of bioavailable $\mathrm{N}$, especially in the rhizosphere. We highlight several biochemical strategies that enable plants and microbes

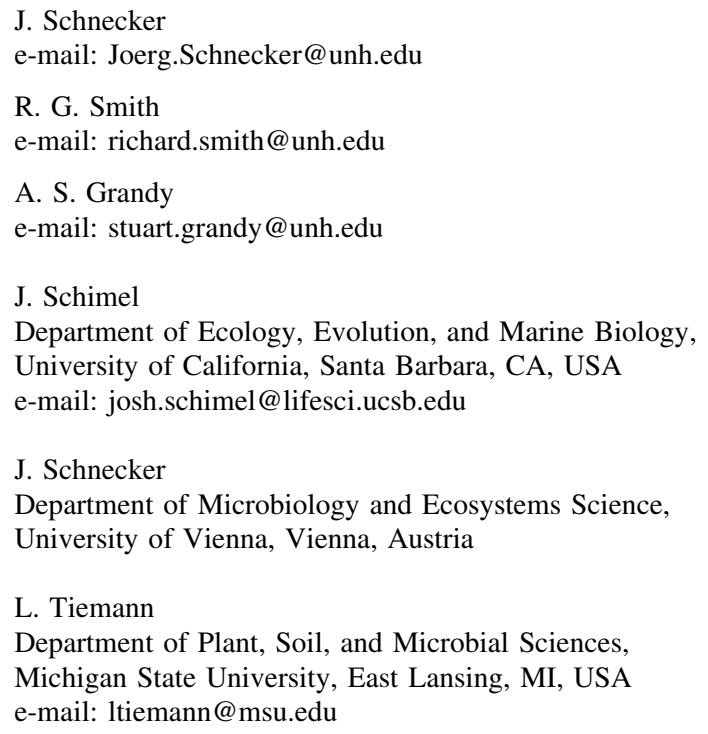


to disrupt mineral-organic interactions and access MAOM. In particular, root-deposited low-molecularweight exudates may enhance the mobilization and solubilization of MAOM, increasing its bioavailability. However, the competitive balance between the possible fates of $\mathrm{N}$ monomers-bound to mineral surfaces versus dissolved and available for assimilation-will depend on the specific interaction between mineral properties, soil solution, mineral-bound organic matter, and microbes. Building off our emerging understanding of MAOM as a source of bioavailable N, we propose a revision of the Schimel and Bennett (Ecology 85:591-602, 2004) model (which emphasizes $\mathrm{N}$ depolymerization), by incorporating MAOM as a potential proximal mediator of bioavailable $\mathrm{N}$.

Keywords Rhizosphere $\cdot \mathrm{N}$ cycling $\cdot$ Soil organic matter · Organo-mineral · Plant-microbial interaction

\section{Introduction}

Nitrogen $(\mathrm{N})$ bioavailability limits plant productivity in most ecosystems. However, it remains challenging to predict bioavailable $\mathrm{N}$ dynamics, particularly in mineral soils, because the specific origins and ultimate fate of $\mathrm{N}$ mobilized from soil organic matter (SOM) are unclear (Niu et al. 2016). Currently, the enzymatic depolymerization of SOM to monomers (e.g., from proteins to amino acids) is thought to be the key ratelimiting step in soil $\mathrm{N}$ mineralization and cycling (Schimel and Bennett 2004). Both microbes and plants can use the N-containing monomers generated by depolymerization (Bardgett et al. 2003; Roberts and Jones 2012), and the resulting competition for monomers can have cascading effects on $\mathrm{N}$ mineralization and bioavailability. Thus, recent research has focused on the mineralization path that $\mathrm{N}$ takes-from polymeric to monomeric and finally to inorganic $\mathrm{N}$ forms-and how these pools and processes influence $\mathrm{N}$ bioavailability or accessibility (Mooshammer et al. 2014; Darrouzet-Nardi and Weintraub 2014).

The focus on pathways of $\mathrm{N}$ mineralization has emphasized $\mathrm{N}$ release from plant litter; by contrast, there has been limited focus on other sources of bioavailable organic $\mathrm{N}$ that may also be important in mineral soils. Moreover, to understand $\mathrm{N}$ dynamics in mineral soils (the main rooting zone in most systems) we must also consider live roots and their localized effects on microbial and nutrient dynamics. These plant-soil interactions are not captured by most laboratory measures of soil $\mathrm{N}$ availability, which usually rely on soils that have live roots cut off during sampling (Hart et al. 1994), and any remaining roots are often removed by sieving. This has led to uncertainties in our understanding of the variability in soil $\mathrm{N}$ pools, availability of $\mathrm{N}$ to organisms, and plant-microbe competition. For example, in many agricultural soils laboratory measures of SOM depolymerization and mineralization correlate only weakly with plant $\mathrm{N}$ uptake or yield (Luce et al. 2011). Field based measurements of net $\mathrm{N}$ mineralization also poorly predict plant $\mathrm{N}$ availability (Abril et al. 2001) and uptake (Monaco et al. 2010). Such results often lead to fertilizer overapplication in agricultural systems (Liu et al. 2010) and then to $\mathrm{N}$ losses from leaching and denitrification. While gross rates of mineralization are higher and may better correlate with plant $\mathrm{N}$ uptake (Osterholz et al. 2016), they are rarely measured at the temporal and spatial scales that are needed to resolve the complex processes that regulate bioavailable $\mathrm{N}$. In addition, many natural ecosystems exhibit a "missing sink" phenomenon wherein soils store more $\mathrm{N}$ than can be accounted for by $\mathrm{N}$ budgeting (Bernal et al. 2012; Yanai et al. 2013; van Groenigen et al. 2015). This suggests there are other pathways of $\mathrm{N}$ storage and production that are not adequately represented by standard laboratory measures of $\mathrm{N}$ availability. Such discrepancies can make it challenging to predict how SOM cycling will respond to environmental stressors such as climate change or $\mathrm{N}$ deposition.

Current conceptual models do not fully account for the pools and processes that supply bioavailable $\mathrm{N}$. Given the emphasis on mineralization from plant litter and microbial detritus, conventional perspectives on SOM maintain that SOM pools that are not physically protected-defined operationally based on particle size or density - are the primary source of plantavailable N. Such pools consist of partially decomposed plant material and are referred to as "light fraction" or "particulate" organic matter pools (Wander 2004; Haynes 2005; Gosling et al. 2013). However, these particulate organic matter (POM) fractions, which are notoriously vulnerable to disturbance (e.g., tillage) (Grandy and Robertson 2007), store only a 
small proportion of total organic $\mathrm{N}$ in some soils (Table 1). In contrast, mineral-associated organic matter (MAOM) fractions, which are defined based on particle size $(<53 \mu \mathrm{m})$ and/or density $\left(>\sim 1.7 \mathrm{~g} \mathrm{~cm}^{-3}\right)$, often hold an order of magnitude or more total $\mathrm{N}$ than POM fractions.
MAOM stores a lot of $\mathrm{N}$, but has a longer turnover time than POM fractions; as a result, it has historically been considered inaccessible to microbes and plants (Fabrizzi et al. 2003; Denef et al. 2013; Paul 2016). Yet, certain attributes of MAOM could make it a substantial $\mathrm{N}$ source. MAOM is enriched in low-

Table 1 Examples from published literature that illustrate the average relative distribution of $\mathrm{N}$ across particle size-based or density fractions in agricultural and non-agricultural systems

\begin{tabular}{|c|c|c|c|c|c|}
\hline System and location & $\begin{array}{l}\text { Depth } \\
(\mathrm{cm})\end{array}$ & $\begin{array}{l}\text { Fractionation } \\
\text { method and } \\
\text { cutoff }\end{array}$ & $\begin{array}{l}\% \mathrm{POM}-\mathrm{N} \text { or } \\
\mathrm{LF}-\mathrm{N} \text { out of } \\
\text { total soil } \mathrm{N}\end{array}$ & $\begin{array}{l}\% \text { MAOM-N } \\
\text { out of total } \\
\text { soil } \mathrm{N}\end{array}$ & References \\
\hline \multicolumn{6}{|l|}{ Agricultural systems } \\
\hline $\begin{array}{l}\text { Tillage studies across } \\
\text { southern USA }\end{array}$ & 5 & $\mathrm{POM}>50 \mu \mathrm{m}$ & $\begin{array}{l}26.0 \\
\quad(3.4-49.6)\end{array}$ & $74.0(50.4-96.6)$ & Schomberg et al. (2009) \\
\hline $\begin{array}{l}\text { Tillage studies in Illinois, } \\
\text { USA }\end{array}$ & 5 & $\mathrm{POM}>53 \mu \mathrm{m}$ & $\begin{array}{l}22.5 \\
\quad(17.1-25.8)\end{array}$ & $77.5(74.2-82.9)$ & $\begin{array}{l}\text { Wander and Bidart } \\
(2000)^{\mathrm{a}}\end{array}$ \\
\hline $\begin{array}{l}\text { Cotton cropping systems in } \\
\text { Texas, USA }\end{array}$ & 5 & $\mathrm{POM}>53 \mu \mathrm{m}$ & $\begin{array}{l}16.5 \\
\quad(13.2-18.9)\end{array}$ & $83.5(81.1-86.8)$ & Bronson et al. $(2004)^{b}$ \\
\hline $\begin{array}{l}\text { Cropping sequence, tillage, } \\
\text { and fertilization studies in } \\
\text { North Dakota, USA }\end{array}$ & 7.5 & $\mathrm{POM}>50-53 \mu \mathrm{m}$ & $\begin{array}{l}32.4 \\
\quad(12.9-43.5)\end{array}$ & $67.6(56.5-87.1)$ & Liebig et al. (2004) \\
\hline $\begin{array}{l}\text { Crop rotation study in } \\
\text { Saskatchewan, Canada }\end{array}$ & 7.5 & $\mathrm{LF}<1.7 \mathrm{Mg} \mathrm{m}^{-3} \mathrm{NaI}$ & $5.8(3.4-8.2)$ & $94.2(91.8-96.6)$ & Biederbeck et al. (1994) \\
\hline $\begin{array}{l}\text { Grass and cereal production } \\
\text { sites in Alberta, Canada }\end{array}$ & 10 & $\mathrm{LF}<1.7 \mathrm{Mg} \mathrm{m}^{-3} \mathrm{NaI}$ & $5.5(4.1-6.9)$ & $94.5(93.1-95.9)$ & Arshad et al. (2004) \\
\hline $\begin{array}{l}\text { Grassland and plantation sites } \\
\text { in south-western Australia }\end{array}$ & 10 & $\mathrm{POM}>45 \mu \mathrm{m}$ & $\begin{array}{l}65.3 \\
\quad(56.7-73.8)\end{array}$ & $34.8(26.2-43.3)$ & Mendham et al. (2004) \\
\hline $\begin{array}{l}\text { Comparing cultivated soil } \\
\text { and field edge in the UK }\end{array}$ & 30 & $\mathrm{LF}<1.7 \mathrm{Mg} \mathrm{m}^{-3} \mathrm{NaI}$ & $13.6(4.3-23)$ & $86.4(77-95.8)$ & Bending et al. $(2002)^{c}$ \\
\hline \multicolumn{6}{|l|}{ Non-agricultural systems } \\
\hline $\begin{array}{l}\text { Temperate deciduous forests } \\
\text { in northeastern USA }\end{array}$ & 5 & $\begin{array}{l}\mathrm{LF}<1.65 \mathrm{Mg} \mathrm{m}^{-3} \\
\quad \mathrm{NaPT}\end{array}$ & $\begin{array}{l}37.3 \\
\quad(29.9-44.7)\end{array}$ & $62.7(55.3-70.1)$ & McFarlane et al. (2013) \\
\hline $\begin{array}{l}\text { Primary and secondary } \\
\text { forests in Puerto Rico }\end{array}$ & 10 & $\begin{array}{l}\mathrm{LF}<1.85 \mathrm{Mg} \mathrm{m}^{-3} \\
\quad \mathrm{NaPT}\end{array}$ & $\begin{array}{l}18.6 \\
\quad(17.8-19.6)\end{array}$ & $81.4(80.4-82.2)$ & $\begin{array}{l}\text { Marin-Spiotta et al. } \\
\text { (2009) }\end{array}$ \\
\hline $\begin{array}{l}\text { Temperate } \\
\text { shrubland/grassland in } \\
\text { Denmark }\end{array}$ & 12.3 & $\begin{array}{l}\mathrm{LF}<1.6 \mathrm{Mg} \mathrm{m}^{-3} \\
\quad \mathrm{NaPT}\end{array}$ & $18(7-29)$ & $82(71-93)$ & Thaysen et al. (2017) \\
\hline Grasslands in China & 15 & $\mathrm{LF}<1.8 \mathrm{Mg} \mathrm{m}^{-3} \mathrm{NaI}$ & 19 & 74 & Ming Shi et al. (2010) ${ }^{\mathrm{d}}$ \\
\hline $\begin{array}{l}\text { Alpine forests in Austrian } \\
\text { Alps }\end{array}$ & 20 & $\begin{array}{l}\mathrm{LF}<2.0 \mathrm{Mg} \mathrm{m}^{-3} \\
\mathrm{NaPT}\end{array}$ & $\begin{array}{l}40.4 \\
\quad(26.7-53.2)\end{array}$ & $59.6(46.8-73.3)$ & Schnecker et al. (2016) \\
\hline
\end{tabular}

The maximum and minimum values are provided in parentheses. If MAOM-N not explicitly provided, value was calculated as POM$\mathrm{N}$ subtracted from total soil N. POM (particulate organic matter), LF (light fraction), NaI (sodium iodide), NaPT (sodium polytungstate). Selected studies do not represent a comprehensive, unbiased literature review but instead are provided to show ranges across varied ecosystem and management contexts

aValues from "location" averages

${ }^{b}$ Values reported for cotton cropping systems only

${ }^{\mathrm{c}}$ Proportion of total organic $\mathrm{N}$

${ }^{\mathrm{d}}$ Single average 
molecular-weight plant compounds (Haddix et al. 2016) and microbial byproducts (Schmidt et al. 2011; Miltner et al. 2012; Kopittke et al. 2017). MAOM thus possesses a low $\mathrm{C} / \mathrm{N}$ ratio (Sollins et al. 2006), which generally promotes $\mathrm{N}$ mineralization (Sollins et al. 1984; Whalen et al. 2000); this is in contrast to POM, which often has a relatively high $\mathrm{C} / \mathrm{N}$ ratio and thus, early in its decomposition, acts as a sink for $\mathrm{N}$ (Whalen et al. 2000; Luce et al. 2011; Fornara et al. 2011). Other recent discoveries also collectively point to the mineralization potential of MAOM (Table 2), which is not uniform; for example, it includes a range of $\mathrm{N}$-rich molecules whose turnover times vary depending on their molecular structure and interaction with different minerals and microbial communities (see sections below). Finally, changes in $\mathrm{pH}$ or soil solution composition can cause organic matter to be mobilized off mineral surfaces, or alternatively to be sorbed onto them (Avena and Koopal 1998; Rashad et al. 2010; Singh et al. 2016). Such variability points to MAOM's potential to serve as an active $\mathrm{N}$ source and sink.

Taking into account the pool size, composition, and mineralization potential of MAOM, we synthesize emerging research to show that the processes regulating MAOM mobilization may be critical, proximal mediators of dissolved organic $\mathrm{N}$ cycling and bioavailability in mineral soils. We discuss the mechanisms that facilitate the release of mineral-associated $\mathrm{N}$, with a particular focus on the rhizosphere where root exudates and microbes enhance its bioavailability to plant roots. There is ample research on the physical and chemical mechanisms that mobilize other nutrients (e.g., phosphorous) from mineral surfaces (Hinsinger 2001; Sharma et al. 2013) and increasing attention on factors controlling organic $\mathrm{N}$ stabilization (Bingham and Cotrufo 2016). However, there is a need to highlight and synthesize evidence for the biological pathways and plant-microbe interactions that govern $\mathrm{N}$ turnover from MAOM. In the sections that follow we describe mechanisms that control the destabilization of MAOM and the role of clay minerals as mediators of bioavailable $\mathrm{N}$ supply, distinguishing between processes that proceed through chemical mechanisms (direct) and those that occur via microbial activities (indirect). Finally, we integrate these ideas into a conceptual framework that extends the Schimel and Bennett (2004) model by incorporating MAOM as a mediator of rhizosphere $\mathrm{N}$ transformations and $\mathrm{N}$ bioavailability (Fig. 1).

\section{Plant exudates enhance the destabilization, solubilization, and accessibility of MAOM}

Belowground plant $\mathrm{C}$ inputs, specifically in the form of root exudates, can suppress or stimulate $\mathrm{C}$ and $\mathrm{N}$ decomposition rates, through a suite of microbial processes collectively known as "priming" (Bingeman et al. 1953; Kuzyakov et al. 2000). Exudates can interact directly with the mineral-organic bonds and thus mobilize MAOM from clays (Keiluweit et al. 2015). Exudates can indirectly influence MAOM mobilization by stimulating a concentrated zone of microbial activity (Kuzyakov 2010) that may facilitate the enzymatic degradation and/or assimilation of MAOM. Both direct and indirect priming mechanisms originate with belowground plant rhizodeposits and could potentially enhance rhizosphere turnover of $\mathrm{N}$ from MAOM, providing a means for both plants and microbes to access $\mathrm{N}$ from this large pool.

\section{Direct destabilization pathways}

In our first pathway, plants increase MAOM bioavailability by producing root exudates that directly interact with mineral surfaces and MAOM. These exudates mobilize MAOM by modifying organomineral interactions and sorption dynamics through mechanisms that do not require microbial intermediaries. Low-molecular-weight organic acids, which are commonly released by plant roots (Oburger et al. 2013; Bowsher et al. 2015), mobilize formerly protected MAOM and thus expose new substrates to microbial degradation and assimilation (Clarholm et al. 2015) (Fig. 2). This destabilizing effect can release sorbed organic compounds into solution. Organic acids can dissolve minerals by decreasing $\mathrm{pH}$ at a local level (Zhang et al. 1985; Zinder et al. 1986). In this case, protonation of a mineral surface can weaken metal-oxygen bonds (Furrer and Stumm 1986; Xu and Gao 2008). Organic acids may also chelate with formerly organic-bound surface cations (Golubev et al. 2006; Wang et al. 2014; Kleber et al. 2015) or compete with binding sites and directly displace MAOM via ligand exchange (Oburger et al. 2009; Keiluweit et al. 2015). These processes can affect both metal oxides and silicate clays, although the potential for MAOM destabilization through this mechanism is generally greater among the former (Golubev et al. 2006). 
Table 2 Evidence for the mineralization potential of mineral organic matter fractions: DF (density fraction/fractionation), PSF (Particle-size based fractionation), LF (light fraction), HF (heavy fraction). Selected studies do not represent a comprehensive, unbiased literature review but instead are provided to show ranges across varied ecosystem and management contexts

\begin{tabular}{|c|c|c|c|c|}
\hline $\begin{array}{l}\text { SOM } \\
\text { fraction }\end{array}$ & $\begin{array}{l}\text { Ecosystem type } \\
\text { and location }\end{array}$ & Methods & Results and implications & References \\
\hline DF & $\begin{array}{l}\text { Agricultural and } \\
\text { forest sites in } \\
\text { northwestern } \\
\text { USA }\end{array}$ & $\begin{array}{l}\text { LF and HF fractions were added to } \\
\text { whole soils. Rates of } \mathrm{C} \text { and } \mathrm{N} \\
\text { mineralization compared against } \\
\text { basal rates in whole soil samples }\end{array}$ & $\begin{array}{l}\mathrm{HF} \text { additions to soil maintained net } \mathrm{N} \\
\text { mineralization rates while } \mathrm{LF} \\
\text { additions led to } \mathrm{N} \text { immobilization }\end{array}$ & $\begin{array}{l}\text { Whalen et al. } \\
\text { (2000) }\end{array}$ \\
\hline DF & $\begin{array}{l}\text { Forest sites in } \\
\text { northwestern } \\
\text { USA and Costa } \\
\text { Rica }\end{array}$ & $\begin{array}{l}\text { Compared net } \mathrm{N} \text { mineralization from } \\
\text { whole soils and isolated LF and } \mathrm{HF} \\
\text { fractions. Soils incubated under } \\
\text { anaerobic conditions }\end{array}$ & $\begin{array}{l}\text { Net } \mathrm{N} \text { mineralization greater from } \mathrm{HF} \\
\text { than LF }\end{array}$ & $\begin{array}{l}\text { Sollins et al. } \\
\text { (1984) }\end{array}$ \\
\hline DF & $\begin{array}{l}\text { Grassland site in } \\
\text { Upper Midwest, } \\
\text { USA }\end{array}$ & $\begin{array}{l}\text { Assessed how the plant effects on } \\
\text { SOM fraction } \mathrm{C} \text { and } \mathrm{N} \\
\text { concentrations mediated changes in } \\
\text { soil } \mathrm{N} \text { mineralization }\end{array}$ & $\begin{array}{l}\text { Plant belowground biomass positively } \\
\text { related to } \mathrm{C} \text { and } \mathrm{N} \text { concentrations of } \\
\text { SOM fractions. Total soil } \mathrm{C} \text { and } \mathrm{N} \text { of } \\
\text { recalcitrant fraction positively } \\
\text { associated with gross } \mathrm{N} \\
\text { mineralization }\end{array}$ & $\begin{array}{l}\text { Fornara et al. } \\
\text { (2011) }\end{array}$ \\
\hline $\begin{array}{l}\text { Acid } \\
\text { hydrolysis }\end{array}$ & $\begin{array}{l}\text { Agricultural site } \\
\text { in northeast } \\
\text { China }\end{array}$ & $\begin{array}{l}\text { Evaluated the fate and seasonal } \\
\text { dynamics of fertilizer } \mathrm{N} \text { across } \\
\text { different organic } \mathrm{N} \text { fractions }\end{array}$ & $\begin{array}{l}\text { The acid insoluble pool stabilized but } \\
\text { not completely protected from } \\
\text { degradation; can be made available } \\
\text { depending on supply and demand }\end{array}$ & $\begin{array}{l}\text { Lu et al. } \\
(2013)\end{array}$ \\
\hline PSF & $\begin{array}{l}\text { Agricultural site } \\
\text { in the North } \\
\text { Island of New } \\
\text { Zealand }\end{array}$ & $\begin{array}{l}\text { Compared } \mathrm{N} \text { mineralization from } \\
\text { sand, silt, and clay fractions in } \\
\text { 18-week incubation }\end{array}$ & $\begin{array}{l}\text { Most } \mathrm{N} \text { mineralization derived from } \\
\text { silt and clay fraction }\end{array}$ & $\begin{array}{l}\text { Parfitt and Salt } \\
\text { (2001) }\end{array}$ \\
\hline N/A & $\begin{array}{l}\text { Grassland site in } \\
\text { north-central } \\
\text { Switzerland }\end{array}$ & $\begin{array}{l}\text { Assessed how elevated } \mathrm{CO}_{2} \text { altered } \mathrm{N} \\
\text { cycling from the recalcitrant } \mathrm{SOM} \\
\text { pool and into plant and microbial } \\
\text { pools. }\end{array}$ & $\begin{array}{l}\text { Delivery of } \mathrm{N} \text { from stable organic } \\
\text { matter; } \mathrm{N} \text { taken up by plants coming } \\
\text { from non-extractable pools }\end{array}$ & $\begin{array}{l}\text { de Graaff et al. } \\
\text { (2009) }\end{array}$ \\
\hline $\begin{array}{l}\text { DF of } \\
\text { particle } \\
\text { size } \\
\text { fractions }\end{array}$ & $\begin{array}{l}\text { Grassland sites in } \\
\text { western } \\
\text { Belgium }\end{array}$ & $\begin{array}{l}\text { Evaluated the relationship between } \mathrm{C} \\
\text { and } \mathrm{N} \text { content of SOM fractions and } \\
\text { gross } \mathrm{N} \text { mineralization rates }\end{array}$ & $\begin{array}{l}\mathrm{N} \text { contents of }<50 \text { and } 50-150 \mu \mathrm{m} \\
\text { fractions explain up to } 97 \% \text { of } \\
\text { variability in gross } \mathrm{N} \text { mineralization } \\
\text { rates; Larger relative importance } \\
\text { of }<50 \mu \mathrm{m} \text { fraction in the } \\
\text { regression model }\end{array}$ & $\begin{array}{l}\text { Accoe et al. } \\
(2004)\end{array}$ \\
\hline PSF & $\begin{array}{l}\text { Grassland site in } \\
\text { England }\end{array}$ & $\begin{array}{l}\text { Examined the contribution of macro- } \\
\text { organic matter } \mathrm{N} \text { to gross } \mathrm{N} \\
\text { mineralization }\end{array}$ & $\begin{array}{l}\text { Macro-organic matter only contributes } \\
2.3-3.4 \% \text { to inorganic } \mathrm{N} \text { pool; } \\
\text { inferred that majority of } \mathrm{N} \text { derived } \\
\text { from mineral-associated pools }\end{array}$ & $\begin{array}{l}\text { Monaghan and } \\
\text { Barraclough } \\
\text { (1997) }\end{array}$ \\
\hline DF & $\begin{array}{l}\text { Forested } \\
\text { chronosequence } \\
\text { in the South } \\
\text { Island of New } \\
\text { Zealand }\end{array}$ & $\begin{array}{l}\text { Measured microbial } \mathrm{N} \text { cycling and } \mathrm{N} \\
\text { functional gene abundance in } \\
\text { incubations of HF fraction and bulk } \\
\text { soil }\end{array}$ & $\begin{array}{l}\mathrm{N} \text { cycling rates and } \mathrm{N} \text {-related } \mathrm{N} \\
\text { functional gene abundance similar or } \\
\text { higher in } \mathrm{HF} \text { compared to bulk soil }\end{array}$ & $\begin{array}{l}\text { Turner et al. } \\
\text { (2017) }\end{array}$ \\
\hline DF & $\begin{array}{l}\text { Harvard Forest } \\
\text { DIRT site in } \\
\text { northeastern } \\
\text { USA }\end{array}$ & $\begin{array}{l}\text { Determined how inclusion/exclusion } \\
\text { of above and belowground plant } \\
\text { inputs influenced the accumulation } \\
\text { of SOM pools }\end{array}$ & $\begin{array}{l}\text { Root inputs did not increase MAOM } \\
\text { pool compared to soils with all } \\
\text { inputs excluded }\end{array}$ & $\begin{array}{l}\text { Lajtha et al. } \\
\text { (2014) }\end{array}$ \\
\hline
\end{tabular}

Recent studies show the capacity of organic acids to destabilize MAOM-C and enhance its degradation. For instance, Keiluweit et al. (2015) used an artificial rhizosphere environment to demonstrate how the metal-chelating capacity of oxalic acid was directly responsible for increased microbial respiration and 


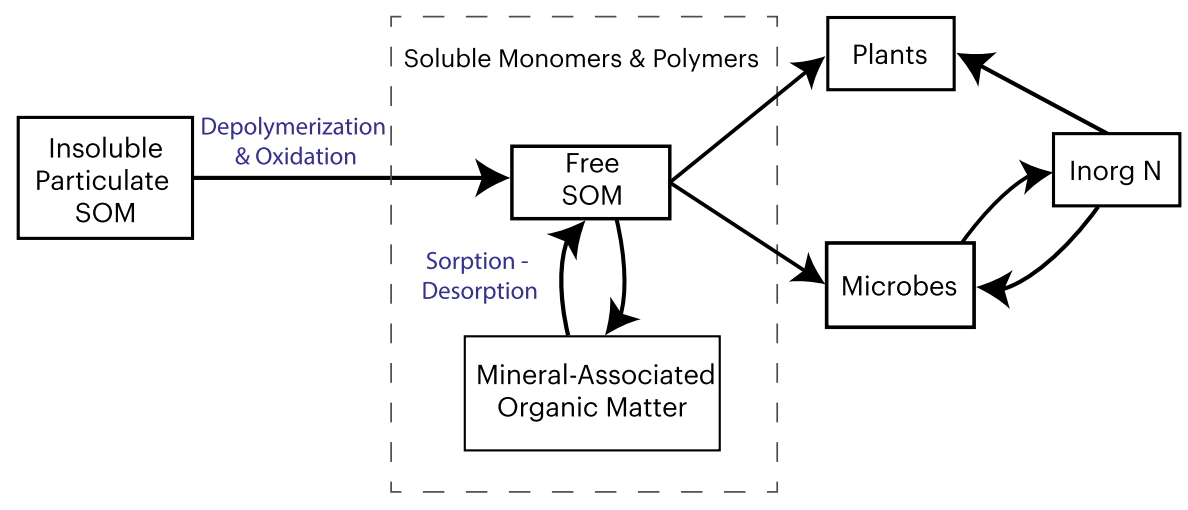

Controls on exchange between MAOM and free pools:

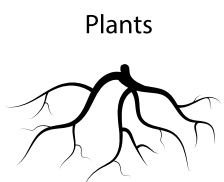

Fig. 1 Conceptual model demonstrating the biological pathways for the production of plant-available N. Adapted from the model originally proposed by Schimel and Bennett (2004), our model highlights the role of mineral-associated organic matter (MAOM) and its continuous and dynamic exchange with the

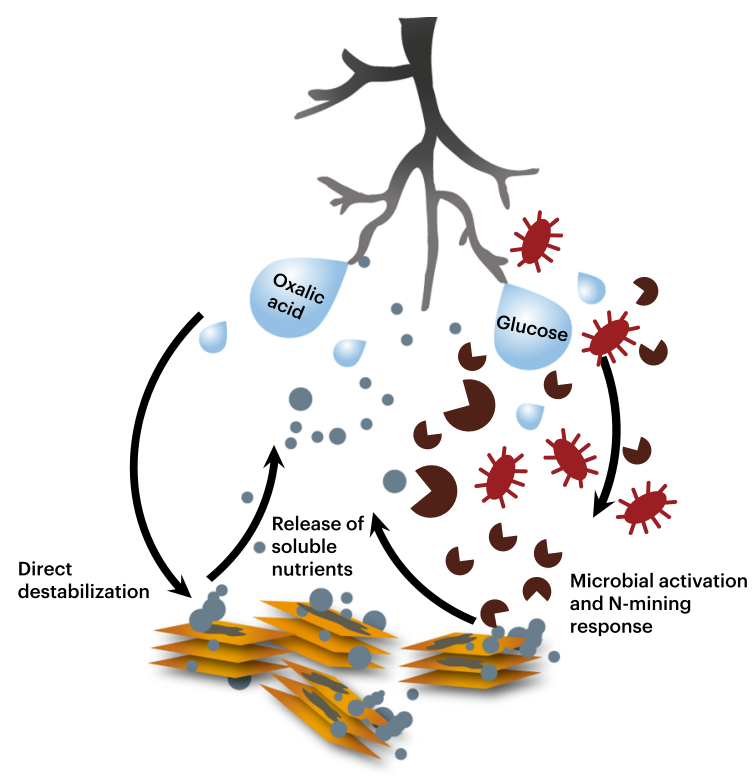

Fig. 2 Illustration depicting the direct and indirect pathways to MAOM destabilization. On the left, oxalic acid can target the organo-mineral bond directly. This pathway bypasses the microbial community to stimulate the release of organic compounds from mineral surfaces. On the right, glucose stimulates the microbial community and activates a microbialmediated $\mathrm{N}$-mining response. These two pathways can work synergistically to further accelerate the degradation and turnover of MAOM within the rhizosphere free and soluble soil organic matter (SOM) pool. Properties of the plants, microbes, and mineral particles will further mediate the exchange of $\mathrm{N}$ between mineral-associated and free pools. The sizes of the boxes do not relate to pool size

soil C loss. Using a natural soil, Wang et al. (2014) observed negligible release of organic $\mathrm{C}$ from mineral surfaces when soil particles were in water, but up to $228 \mathrm{mg} \mathrm{C} \mathrm{L} \mathrm{L}^{-1} \mathrm{~g}^{-1}$ organic $\mathrm{C}$ was released with the addition of organic acids (citric and malic acid). This release was attributed to dissolution of metals like $\mathrm{Fe}^{3+}$ and $\mathrm{Al}^{3+}$, components of the mineral fraction that can stabilize organic compounds via strong ligand bonds. The evidence for organic acid-induced destabilization and solubilization of organics from mineral surfaces suggests this could be an important chemical pathway for mobilizing MAOM in the rhizosphere. Further, considering the low $\mathrm{C} / \mathrm{N}$ ratio of MAOM, organic acids could destabilize even greater amounts of $\mathrm{N}$ relative to the $\mathrm{C}$ they mobilize. Although organic acid production is associated with enhanced $\mathrm{N}$ availability (Pan et al. 2016), no study has directly assessed how organo-mineral structures modulate the effect of organic acids on $\mathrm{N}$ cycling.

More broadly, exogenous dissolved organic matter (DOM) inputs such as root exudates can interact with endogenous organic compounds to mobilize MAOM (Toosi et al. 2012) or cause dissolved materials to precipitate onto minerals (Halvorson et al. 2016). For example, new DOM inputs exchange rapidly with existing mineral-sorbed OM, and this exchange can 
mediate both the quantity and quality of $\mathrm{OM}$ in solution (Sanderman et al. 2008). Mineral-bound organic $\mathrm{N}$ is particularly vulnerable to exchange by incoming DOM (Scott and Rothstein 2014) due to the propensity for hydrophobic compounds to displace $\mathrm{N}$-rich and typically more hydrophilic compounds. This is frequently observed across soil profiles where DOC is preferentially retained in surface soils while $\mathrm{N}$-rich and hydrophilic compounds dominate subsurface and mineral horizons (Lajtha et al. 2005). Minerals also serve as hotspots for biogeochemical interactions between mineral surfaces, microbes, and OM (Kaiser and Kalbitz 2012; Leinemann et al. 2018). Thus, the exchange of OM between free and mineralbound pools may also be microbially mediated. In the rhizosphere, plants could potentially intercept this microbially transformed and N-rich DOM. It is important to account for the role of root exudates in facilitating these sorption-desorption processes and how it may be a means for plants to acquire $\mathrm{N}$ from MAOM.

\section{Indirect destabilization pathways}

Root exudates can also enhance SOM degradation indirectly by stimulating microbial activity and "priming" (Kuzyakov 2010; Zhu et al. 2014). The leading priming hypothesis states that labile exudates enhance microbial activity by alleviating microbial $\mathrm{C}$ or energy limitations (DeAngelis et al. 2008; Chen et al. 2014; Zhu et al. 2014). This priming effect has been studied mainly for its role in altering whole soil $\mathrm{C}$ or $\mathrm{N}$ cycling and without regard for the specific origin of mobilized nutrients. However, given the quantity and chemistry of $\mathrm{N}$ within MAOM, and the varied nature of organo-mineral interactions, this pool may be vulnerable to priming and an important source of $\mathrm{N}$ in the rhizosphere.

The priming effect can elicit a strong N-mining response (Rousk et al. 2016) by stimulating N-degrading microbial communities (Fontaine et al. 2011), accelerating $\mathrm{N}$-acquiring enzyme activity (Phillips et al. 2011; Meier et al. 2017) and enhancing gross $\mathrm{N}$-mineralization rates (Herman et al. 2006; Dijkstra et al. 2009; Zhu et al. 2014; Finzi et al. 2015). Resulting increases in soil $\mathrm{N}$ cycling can also be tied to greater N uptake by trees (Drake et al. 2011). Along with the positive rhizosphere effect on $\mathrm{N}$-acquiring enzyme activities (Koranda et al. 2011; Ciadamidaro et al. 2014; Loeppmann et al. 2016), plants can also stimulate the microbial production of oxidative enzymes, like laccase, peroxidase and phenol oxidase (Carney et al. 2007; Phillips et al. 2011; Partavian et al., 2015).

As opposed to hydrolytic enzymes, which operate on a lock-and-key mechanism, oxidative enzymes do not exhibit substrate specificity (Allison 2006). They can attack a variety of chemical bonds, such as those in aromatic compounds, and can also catalyze decarboxylation and demethylation reactions (Call and Mücke 1997). Such versatility in catalytic capacity may allow oxidative enzymes to initiate the first step in the breakdown of complex organic matter or destabilization of mineral-bound compounds-thereafter exposing substrates to downstream attack by hydrolytic enzymes. Oxidative enzymes are generally associated with the release of bioavailable $\mathrm{C}$, but may also be a means to access organic $\mathrm{N}$ in the rhizosphere (Sinsabaugh 2009; Kieloaho et al. 2016). For example, Zhu et al. (2014) observed a positive relationship between oxidative enzyme activity and gross $\mathrm{N}$ mineralization rates in response to priming, while Kieloaho et al. (2016) found both oxidative and protease enzymes activities were needed to release $\mathrm{N}$ from both protected and bioavailable $\mathrm{N}$ pools.

The preferential synthesis of $\mathrm{N}$ over $\mathrm{C}$-acquiring enzymes by rhizosphere microbes can slow $\mathrm{C}$ mineralization and accelerate $\mathrm{N}$ mineralization, decoupling the processes. For example, Rousk et al. (2016) found that glucose amendments increased gross $\mathrm{N}$ mineralization by $100-300 \%$, but reduced $\mathrm{C}$ mineralization up to $60 \%$. The authors argued that increased root exudation can stimulate a shift from $\mathrm{C}$ to $\mathrm{N}$-acquiring enzymes-indicative of an N-mining response, or a specific shift toward N-rich compounds (Rousk et al. 2016). Similarly, Murphy et al. (2015) observed that simulated root exudates mobilized a pool of SOM with a relatively low $\mathrm{C} / \mathrm{N}$ ratio when compared against unprimed soils. In other studies, $\mathrm{C}$ exudation and $\mathrm{N}$ mineralization rates were positively correlated with increased $\mathrm{N}$-acquiring enzyme activity (Brzostek et al. 2013), phenol oxidase activities, and subsequent $\mathrm{N}$ transformation rates (Yin et al. 2013).

It remains unclear whether MAOM or other fractions are targeted by N-mining microbes, but the siltand clay-sized soil fraction consists of biologically active microenvironments with an intrinsic N-supplying capacity that could benefit rapidly growing and 
$\mathrm{N}$-limited rhizosphere microbes. While conventional thinking is that enzymes are no longer active following sorption onto mineral surfaces (e.g. Quiquampoix et al. 1993), there are many reported cases of sorption either enhancing (Tietjen and Wetzel 2003) or having no influence (Gianfreda and Bollag 1994) over enzymatic activity. Further, mineral surfaces can protect enzyme activity from environmental changes in $\mathrm{pH}$, temperature, and ionic strength (Kim et al. 2012; Schimel et al. 2017), and the highest enzyme activities are typically found in MAOM fractions (Grandy et al. 2008; Lagomarsino et al. 2012; Zhang et al. 2016).

Land use and global change studies provide a platform for understanding the root-driven priming of MAOM and any potential ecosystem-level consequences. Under elevated $\mathrm{CO}_{2}$ and ozone $\left(\mathrm{O}_{3}\right)$, enhanced rhizodeposition accelerates decomposition, microbial $\mathrm{N}$ uptake, and $\mathrm{N}$ mineralization (Hofmockel et al. 2011; Phillips et al. 2012). This acceleration of C and $\mathrm{N}$ cycles has been tied to a greater vulnerability of MAOM to priming (Carney et al. 2007). Likewise, elevated $\mathrm{CO}_{2}$ can lead to significantly more loss of $\mathrm{C}$ and $\mathrm{N}$ from older or mineral-associated fractions (Dorodnikov et al. 2011; Hofmockel et al. 2011). In a study investigating long-term reforestation, Mobley et al. (2015) and Richter et al. (1999) observed significant losses in subsoil SOM, possibly as a result of priming by new root growth. Thus, rhizodeposition may accelerate the cycling of mineral-associated pools of SOM; this increased turnover of $\mathrm{N}$ from MAOM may either prevent or ameliorate plant $\mathrm{N}$-limitation. As terrestrial ecosystems experience global change effects, MAOM may become an increasingly important source of $\mathrm{N}$ for plants and microbes.

\section{Drivers of direct and indirect MAOM destabilization}

While MAOM is N-rich and is a potentially accessible soil fraction, specific properties of the interacting clays, organic matter, and microbes will influence its bioavailability. Minerals have a wide range of chemical and physical properties; similarly, organic compounds vary in molecular structure, functional group chemistry, and charge characteristics. Collectively, these properties determine the strength of organomineral associations and in turn, their susceptibility to destabilization. Aspects of the microbial community, such as the physiological and compositional response to labile $\mathrm{C}$ inputs, may additionally mediate the extent of MAOM destabilization and degradation.

Strength of organo-mineral associations

The bond strength between organic compounds and mineral surfaces influences the vulnerability of MAOM to destabilization. The strength and nature of surface interactions are controlled by properties of the organic compound (i.e., type, abundance, charge characteristics of surface functional groups) and of the mineral particle (i.e., size, shape and topography) (Kleber et al. 2015). Although chemical sorption can establish a bond that makes a molecule resistant to oxidation and degradation, many organo-mineral sorption interactions are also reversible. Sorbates interact via short- or long-range atomic interactions with varying bond strengths-e.g., polar covalent bonds have bond energies greater than $100 \mathrm{~kJ} \mathrm{~mol}^{-1}$ while bond energies associated with weaker van der Waals or hydrogen bonds range between 2 and $12 \mathrm{~kJ} \mathrm{~mol}^{-1}$ (Kleber et al. 2015; Violante and Caporale 2015).

Mineral identity plays a major role in the nature of organo-mineral bonds (Singh et al. 2017) (Fig. 3) and potentially in MAOM bioavailability. For example, relatively low-charge clays such as kaolinite will bind organic $\mathrm{N}$ more loosely than smectites or other expandable clays with a negative surface charge (Mikutta et al. 2010; Yu et al. 2013). These less reactive phyllosilicates may be more likely to deliver $\mathrm{N}$ to plants. Clays with greater sorptivity, such as 2:1 phyllosilicates, may compete more strongly against microbes for organic $\mathrm{N}$ monomers or oligomers (Dippold et al. 2014). Iron and aluminum oxides have an even stronger capacity to bind organic $\mathrm{N}$ than most phyllosilicate clays (Kaiser and Zech 2000; Kleber et al. 2005), but some microbial metabolites associated with these surfaces can still be readily available to microbes (Swenson et al. 2015). Certain minerals, such as manganese oxides can catalyze the fragmentation of proteins (Reardon et al. 2016). Thus, the relationship between clay identity and MAOM-N stability warrants further investigation. In a recent case, including mineralogical parameters significantly improved multivariate models describing $\mathrm{N}$ mineralization in agricultural soils (Wade et al. 2018). Similar 


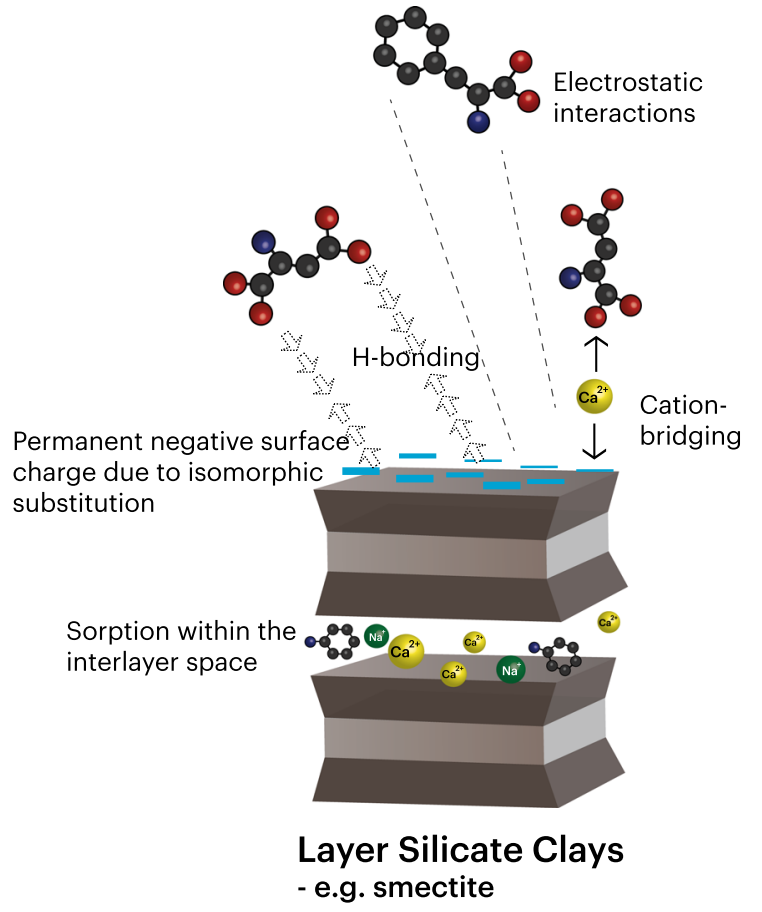

Fig. 3 Illustration of two mineral types and examples of the variety of bonding mechanisms that can be associated with each. While the organo-mineral associations are not mutually exclusive, the predominant mechanisms of association differ

work is needed across a wide range of ecosystems to understand how mineralogy mediates the turnover of soil N. While mineralogical composition can drive the extent of soil $\mathrm{C}$ priming by fresh litter inputs (Rasmussen et al. 2007), its role in priming soil $\mathrm{N}$ is poorly understood, despite the clear influence of mineral composition over SOM chemistry and binding strength.

Mineral surface chemistry further interacts with the specific chemistry of organic compounds to determine the binding mechanisms ultimately involved in stabilizing organic matter. While there is a range of compound types and binding mechanisms, here we focus on amino acids, which are the most abundant form of N-containing monomer in many soils (Knicker 2011) and likely a dominant by-product of degradation processes occurring at the organo-mineral interface. In addition, mineral surfaces can re-adsorb amino acids generated in this zone of dynamic exchange. Minerals "compete" with plants and microbes for liberated amino acids, thus making mobilization from mineral surfaces a potential rate-limiting step for amino acid bioavailability.

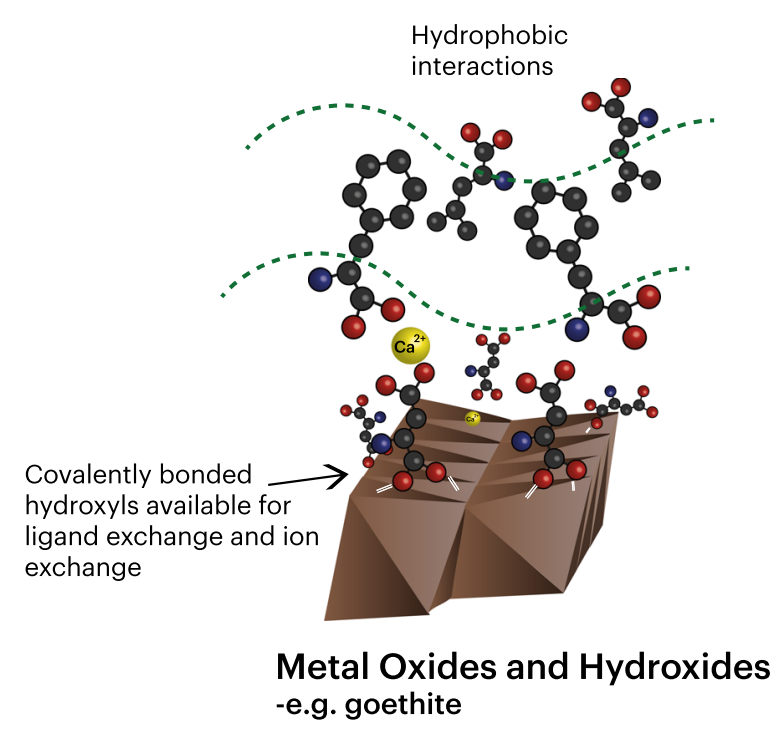

across clay types leading to variation in bonding strength among minerals. Blue and red circles represent nitrogen and oxygen, respectively

Amino acids bind to mineral surfaces readily, but the interaction depends on their overall charge and side group chemistry as well as solution $\mathrm{pH}$ (Theng 1974; Lambert 2008; Dippold et al. 2014). However, sorption does not necessarily reduce bioavailability. Microbes colonize mineral surfaces (Uroz et al. 2015), bringing substrates and their potential degraders into proximity. In some cases, permeases (membrane transport proteins) have a higher affinity for amino acids than do adjacent mineral surfaces (Dashman and Stotzky 1986) allowing microbial uptake of amino acids to outcompete mineral sorption (Fischer et al. 2010). The rate of amino acid sorption can also depend on the chemistry of pre-existing MAOM, where some compounds, such as phenolic acids, can enhance the sorption of amino acids (Gao et al. 2017). The specific chemistry of binding sites may therefore matter more than the number of binding sites in determining overall sorption potential of minerals. In the rhizosphere, the high density of microbial populations coupled to changes in $\mathrm{pH}$ could stimulate the release of mineralassociated amino acids. 
Microbial community dynamics

The availability of $\mathrm{N}$ to plants is largely regulated by root-associated microbes and their access to, and utilization of, soil nutrients (Reynolds et al. 2003; Richardson et al. 2009). As such, specific properties of rhizosphere microbes, such as their abundance, physiology, and community composition, may mediate the magnitude/direction of the priming effect and the amount of MAOM destabilized via priming (Zechmeister-Boltenstern et al. 2015). For example, the C and $\mathrm{N}$ use efficiency (CUE, NUE) of the microbial community, coupled with its cellular stoichiometry, will determine nutrient demand (Sinsabaugh et al. 2013; Wieder et al. 2015; Geyer et al. 2016). As microbial CUE increases, $\mathrm{N}$ demand and NUE may also increase in order to maintain cellular $\mathrm{C} / \mathrm{N}$ ratios (Mooshammer et al. 2014), resulting in an enhanced $\mathrm{N}$-mining response to root exudation. That is, as root exudates provide a labile $\mathrm{C}$ source and microbial $\mathrm{C}$ needs are satisfied, microbes will invest more resources into enzyme production in order to acquire $\mathrm{N}$ from MAOM. In contrast to scenarios where CUE is high, microbes that use $\mathrm{C}$ inefficiently will require less $\mathrm{N}$, and will consequently show a depressed $\mathrm{N}$ mining response to root exudation (Mooshammer et al. 2014). Further, microbial CUE and NUE also constrain microbial biomass, turnover, and activity, which will have feedbacks to the cycling and bioavailability of MAOM-N (Sinsabaugh et al. 2016).

Microbes also produce a diverse array of metabolites and enzymes that likely vary in their capacity to destabilize MAOM. For example, some microbes produce organic acids such as malate, citrate, and oxalate, which have a high affinity for trivalent metal cations that bind organics to mineral surface (Jones 1998); by mobilizing the metals, it could release associated organic matter. In contrast, microbial taxa that produce organic acids with limited metal complexing capacities, such as lactate, formate, and acetate (Jones 1998), may be less able to access MAOM. Microbes capable of oxidative enzyme production may have a disproportionate impact on MAOM destabilization. Microbial synthesis of lignindegrading and other oxidative enzymes serves to release $\mathrm{N}$ from organic matter (Craine et al. 2007; Shukla and Varma 2011; Rinkes et al. 2016); more specifically, oxidative attack may be an important pathway for fungi to acquire $\mathrm{N}$ in macromolecular structures, like protein-polyphenol complexes (Bending and Read 1996). Indeed, peroxidase enzymes have been characterized as a "proximate control for $\mathrm{C}$ and N mineralization" (Tian et al. 2010).

Important microbes that produce oxidative enzymes to access $\mathrm{N}$ include ectomycorrhizal fungi (EMF) and lignin-degrading saprotrophs (Talbot et al. 2008; Sinsabaugh 2009). Certain groups of EMF may have the capacity to liberate and assimilate mineral-bound forms of organic $\mathrm{N}$; hydrophobic EMF may be better equipped in this regard due to their capacity to access more insoluble forms of $\mathrm{N}$ (Hobbie et al. 2012; Chen et al. 2016). Not all lineages of EMF are uniformly equipped to produce oxidative enzymes (Pellitier and Zak 2018) and other fungi, such as saprotrophic or ericoid mycorrhizal fungi, have an overall greater capacity to produce such enzymes (Bending and Read 1996; Wu 2011). More studies are needed to identify the fungal taxa that can produce the enzymes needed to mobilize $\mathrm{N}$ from MAOM.

By extending the root surface area for plants, mycorrhizal fungi may increase the opportunity for a plant to acquire $\mathrm{N}$ from MAOM, especially MAOM contained within aggregates. Both EMF and arbuscular mycorrhizal fungi are known to enhance soil aggregate formation and stabilization (Rillig and Mummey 2006; Zheng et al. 2014), but they also have the capacity to explore the interior of aggregates. Mycorrhizal hyphae can penetrate aggregates and so overcome the physical barrier a macro- or microaggregate might present that would protect MAOM. However, research thus far has not addressed if or how fungal, and specifically EMF, entry into a macro- or micro-aggregate mobilizes $\mathrm{N}$-containing MAOM contained within.

Microbes can also weather minerals through both physical and biochemical mechanisms, which could ultimately solubilize compounds from MAOM. Mineral colonization by fungi can lead to biomechanical weathering-hyphal pressure can be strong enough to physically alter clay surfaces (Bonneville et al. 2009). Biochemical weathering can result from the action of bacterial and fungal chelators (Burford et al. 2006), protons or siderophores that can alter the chemical structure or behavior of clays (Gadd 2010; Courty et al. 2010). Among the fungal groups, ectomycorrhizal fungi may play an outsized role in weathering (Van Breeman et al. 2000) although recent evidence suggests both arbuscular and ectomycorrhizal fungi 
may have comparable effects on mineral weathering rates (Koele et al. 2014; Remiszewski et al. 2016).

Generally, clay weathering is considered a slow pedogenic process, but it can occur over decadal or sub-annual time scales, especially within the rhizosphere. Processes occurring at the root-soil interface can accelerate pedogenesis such that mineral dissolution or alteration can occur within 20 years (Calvaruso et al. 2009; Mareschal et al. 2013) or even within a growing season (Paola et al. 2016). Through these microbial-driven weathering processes, it is possible that MAOM could become released into the surrounding soil solution. However, these studies are typically conducted in pure culture environments and with the mineral substrate being minimally weathered primary mineral or pure clay minerals. It is also important to consider the potential contribution of bedrock $\mathrm{N}$ - up to $17 \%$ of $\mathrm{N}$ in natural systems may be derived from modern-day rock $\mathrm{N}$, upending the conventional assumption that the atmosphere is the ultimate and primary source of $\mathrm{N}$ (Houlton et al. 2018). Thus, it is possible that in the rhizosphere, plant and microbialinduced weathering can mobilize $\mathrm{N}$ from both the minerals and the associated SOM.

\section{Synthesis: proposed conceptual framework}

Building on the mechanisms of destabilization described here, we propose to reconsider Schimel and Bennett's model of soil $\mathrm{N}$ bioavailability by incorporating MAOM as a mediator of rhizosphere $\mathrm{N}$ transformations and $\mathrm{N}$ bioavailability (Fig. 1). In our revised model, SOM is split into particulate and soluble pools. Particulate SOM consists of polymeric compounds-essentially plant litter-which must be enzymatically degraded by microbes in order to release soluble components that can be accessed. The soluble pool contains some polymers, such as protein oligomers, and monomers, such as amino acids (Warren 2013). This retention of smaller soluble SOM compounds by mineral surfaces can restrict their accessibility to microbes and plants. Byproducts from microbial turnover can accumulate on surfaces and so contribute to further building MAOM (Grandy and Neff 2008). However, plant root exudates can remobilize MAOM into the soil solution, thus making SOM "free" and accessible to microbes (and their enzymes) and to plants.
Our revised framework emphasizes spatially-explicit processes occurring in the rhizosphere, where high microbial activity and the influx of low molecular weight $\mathrm{C}$ compounds (i.e., exudation) intensifies sorption/desorption of organic $\mathrm{N}$ and plant-microbial competition for these compounds. Root exudation, by modifying the soil solution and microbial community, regulates the accessibility of $\mathrm{N}$ in MAOM pools. It is likely that the direct and indirect pathways of MAOM destabilization, as previously described, interact synergistically. That is, as organic acids target MAOM, adjacent enzymes can degrade newly freed polymers. At the same time, the chemical properties of mineral surfaces may mediate the accessibility of MOAM in the rhizosphere. For example, N-containing compounds that are weakly associated with weathered silicate clays may be more vulnerable to destabilization.

In both Schimel and Bennett's model and our own, a critical source of bioavailable $\mathrm{N}$ is protein depolymerization. However, whereas Schimel and Bennett (2004) developed their model with a focus on plant material and how $\mathrm{N}$ moves from litter to microbes and plant roots; in mineral-dominated soils there's now ample evidence that minerals are a dynamic source and sink for bioavailable $\mathrm{N}$ that can strongly influence overall $\mathrm{N}$-availability. By providing an additional and distinct $\mathrm{N}$ source, MAOM is also likely to have consequences for plant and microbial $\mathrm{N}$ acquisition. For example, plant-microbe competition for MAOM in the rhizosphere is likely distinct from competition occurring in bulk soil or within particulate organic matter patches. In bulk soil, where roots and microbes are disconnected, diffusion limitations drive competition for $\mathrm{N}$ between plants and microbes (Kuzyakov and $\mathrm{Xu}$ 2013) (Fig. 4a); $\mathrm{N}$ recycles through the microbial community and may only reach the plant when microbial $\mathrm{N}$ needs are met (Mooshammer et al. 2014). Alternatively, in POM-rich patches colonized by roots and their associated hyphae, plants and microbes are in more direct competition. Plants can more effectively intercept $\mathrm{N}$ when associated with mycorrhizal fungi (Cavagnaro et al. 2012) and they can also intercept $\mathrm{N}$ released from the turnover of $\mathrm{N}$-limited microbes (Fig. 4b). Due to temporal niche differentiation, both plants and microbes can acquire $\mathrm{N}$ from these litter patches: while microbes take up $\mathrm{N}$ quickly, their populations turn over rapidly, cycling $\mathrm{N}$ back into the form that plants can compete for and 


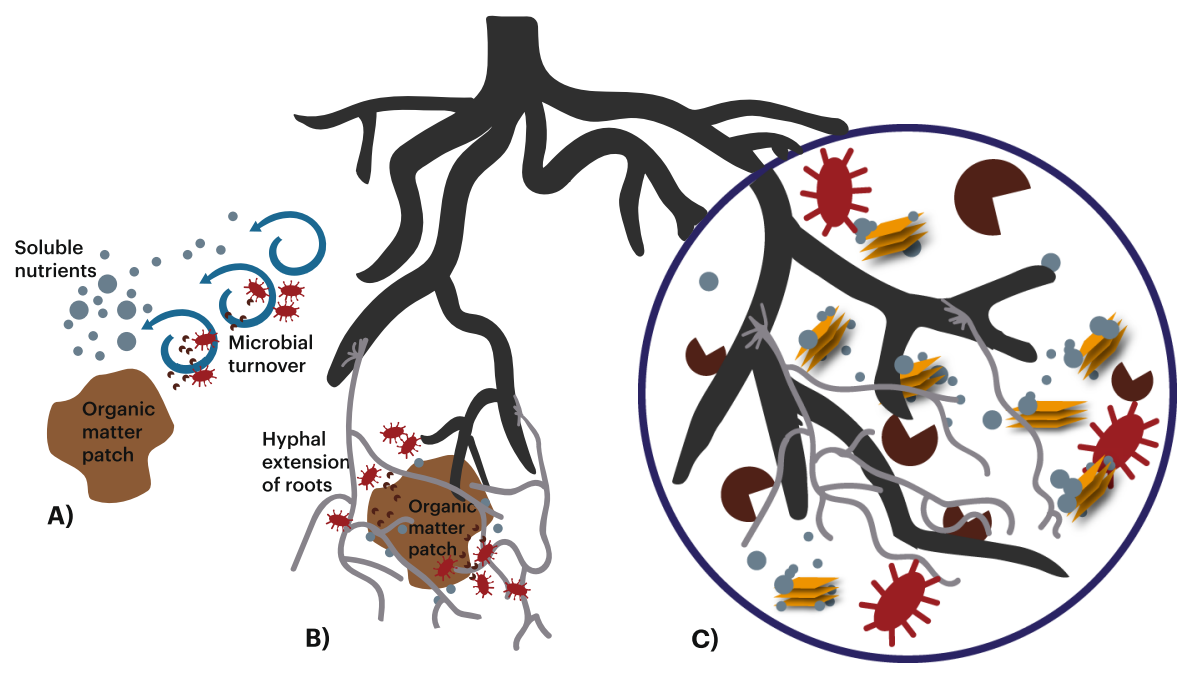

Fig. 4 Illustration of three distinct scenarios of plant-microbial competition for $\mathrm{N}$. In scenario $\mathrm{A}$, diffusion limitations drive competition for $\mathrm{N}$ between plants and microbes. In scenario $\mathrm{B}$, where roots and their associated hyphae colonize POM- or litter-

rich patches, plants and microbes are in more direct competition. In scenario $\mathrm{C}$, a tight coupling of $\mathrm{C}$ and $\mathrm{N}$ cycling provides microbes $\mathrm{C}$ and plants $\mathrm{N}$, leading to a cooperative dynamic

store for a more extended time. Thus, over time, $\mathrm{N}$ moves from the microbial biomass into plants (Hodge et al. 2000; Kuzyakov and Xu 2013).

These scenarios are likely distinct from those in which plants and microbes acquire $\mathrm{N}$ from MAOM in the rhizosphere. Root exudates stimulate microbial activity, driving microbial mining and mineralization of $\mathrm{N}$, some of which could be derived from MAOM. As this is driven by root exudate inputs, it occurs along the root plane where plants can access the released $\mathrm{N}$. Plants deplete $\mathrm{N}$ from solution, which further accelerates the $\mathrm{N}$-mining response and enhances desorption from mineral surfaces. This plant-microbial interaction serves to drive $\mathrm{N}$ off of mineral surfaces. Thus, a tight coupling of $\mathrm{C}$ and $\mathrm{N}$ cycling provides microbes $\mathrm{C}$ and plants $\mathrm{N}$, leading to a cooperative dynamic distinct from the more competitive ones occurring in patches of labile POM or in the bulk soil (Fig. 4c).

\section{Future research opportunities}

Developing a more quantitative understanding of MAOM's N cycling capacity has been limited in part by the analytical scale of most SOM studies. Prevailing perspectives on SOM mineralization are based on analyses conducted on whole-soil samples, whereas critical zones of activity, such as those in the

rhizosphere or on mineral surfaces, operate at a much smaller scale $\left(\mathrm{nm}^{3}-\mathrm{mm}^{3}\right)$. Standard chemical extractions and fractionations may attenuate or overlook the micro- and nano-scale processes that govern MAOM transformations. Even isotope-based studies, which can disentangle chemical processes, are still usually applied to whole soil samples-although NanoSIMS can analyze $\mathrm{N}$ dynamics at the micro-scale (Herrmann et al. 2007).

Disentangling the functional role of MAOM and the ways in which plants and microbes access and interact with it will require fine-scale and minimally destructive techniques. Tracing and quantifying the $\mathrm{N}$-supplying capacity of MAOM will also require experiments that include a live plant or that mimic the action of roots. The mechanisms described in this paper may be most relevant where there is a constant drawdown of soluble $\mathrm{N}$. This would maintain the $\mathrm{N}$-mining activities of both roots and microbes, which may otherwise be suppressed in standard incubation experiments where soluble nutrients can accumulate (Fog 1988; Craine et al. 2007). We also recommend that future research employ high resolution techniques such as stable-isotope probing, which can be used to trace the fate of $\mathrm{C}$ and $\mathrm{N}$ through living and non-living soil pools. Combining stable-isotope methods with emerging techniques for characterizing molecular and chemical composition will be valuable for examining 
the cycling of nutrients at the organo-mineral interface and the role of plants (e.g., see Pett-Ridge and Firestone 2017). By incorporating these ideas into existing and future models, we may also improve our theoretical understanding and practical management of the $\mathrm{N}$ cycle.

Our revised model emphasizing minerals as a source and sink for bioavailable $\mathrm{N}$ should encourage new avenues of research that foster collaborations among biogeochemistry, ecology, and soil science. For example, priming studies, thus far, have largely focused on specific mechanisms and short-term (daysto months-long) effects (Huo et al. 2017). To better understand how priming influences MAOM turnover and the potential consequences for ecosystem function, it will be important to link fine-scale geochemical processes with higher- level and longer-term ecosystem responses. By integrating across diverse spatial and temporal scales, we can explore MAOM's role through a more interdisciplinary lens.

To that end, we suggest the following potential avenues for future research, broadly categorized by spatial scale. This is intended to highlight emerging topics related to MAOM destabilization and the release of bioavailable $\mathrm{N}$.

(1) At the meter to ecosystem scale, the most basic questions remain: how much $\mathrm{N}$ do plants and microbes acquire from MAOM in different ecosystems, and what is the turnover time of $\mathrm{N}$ compounds in the MAOM pool? We have provided evidence based on pool size, variable turnover rates, "missing" $\mathrm{N}$ sinks, and our emerging understanding of priming, which all suggest that MAOM is a dynamic pool of N. Yet more direct measurements of plant and microbial uptake of MAOM-N are needed. Further, questions remain regarding how plant traits, such as root exudate profiles, influence the potential for MAOM degradation. Certain plant species may host rhizosphere microbial communities that are more effective at solubilizing MAOM. It is possible that such traits could confer plants with a competitive advantage, thus altering plant-community dynamics and succession over time.

(2) At the micro-meter scale, patterns of enzyme induction and microbial investment in organic $\mathrm{N}$ acquisition will depend on microbial traits.
We know how individual morphological and physiological traits may translate into different abilities to access MAOM-N, but we do not fully understand how this manifests within diverse microbial communities. In theory, CUE and NUE should be tightly coupled to MAOM-N acquisition. If this is true, changes in environmental conditions that alter microbial physiology could have strong effects on MAOM-N dynamics. We need to better understand the role that mycorrhizal fungi play in accessing MAOM. By extending root surface area, transporting $\mathrm{N}$, and producing degradative enzymes, they may enhance MAOM-N bioavailability.

(3) At the nano-meter scale, we need to better define and measure the "kinetic zone" at the organo-mineral interface (Kleber et al. 2007). It is not clear how or under what conditions enzymes overcome organo-mineral associations. Oxidative enzymes can generate free radicals that further decompose SOM (Dashtban et al. 2010). Can these small, diffusible oxidizers access and decompose MAOM regardless of the strength of the mineral-organic bond? Alternatively, are enzymes only capable of attacking weakly held compounds, such as those associated with highly weathered minerals?

(4) Finally, there is a need to investigate processes occurring at pedon scales: the role of soil physical properties, such as pore and aggregate dynamics, and how specific microbial community members may be more or less equipped physiologically to access MAOM. Recent research begins to address the interactions of pore size/connectivity and soil moisture in driving the turnover of SOM cycling (Bailey et al. 2017; Smith et al. 2017); this remains a key question in understanding the fate of MAOM and microbes' abilities to access the $\mathrm{N}$ in these protected pools.

The importance of MAOM as a source of $\mathrm{N}$ to plants and microbes will likely vary among ecosystems depending on management as well as climate, vegetation and edaphic soil properties. The proportion of $\mathrm{N}$ stored as MAOM relative to particulate sources may determine the potential rate of MAOM-N 
turnover within the rhizosphere. For example, in organic soils or N-limited environments, which served as the context for the model originally proposed by Schimel and Bennett (2004), depolymerization (Delgado-Baquerizo and Gallardo 2011) or mycorrhizal N transfer (Högberg et al. 2017) may more strongly limit $\mathrm{N}$ availability than minerals. In contrast, MAOM may be a more significant source of $\mathrm{N}$ in agricultural soils, where proportionally more $\mathrm{N}$ is stored as MAOM than POM. However, the relative distribution of $\mathrm{N}$ across SOM fractions will not be the only determinant. Other interacting factors, such as MAOM chemical composition (e.g., the abundance of monomeric vs. polymeric N) and mineral assemblage (e.g., the abundance of highly reactive versus low-charge clays) will influence if and how plants and microbes can access $\mathrm{N}$ within MAOM. In certain ecosystems, mineral subsoils may be a more important source of $\mathrm{N}$ where plants with deeper rooting systems could access and extract $\mathrm{N}$ from MAOM. Moisture and temperature are additional controls, which may alter the rate of MAOM turnover and/or mediate whether mobilized $\mathrm{N}$ remains within a physically isolated microbial community or can translocate through the pore spaces. New research on the role of MAOM in $\mathrm{N}$ cycling across different ecosystems and spatio-temporal scales is needed to understand how these factors interact and to determine where MAOM-N cycling is most relevant. This will also allow us to move from the conceptual framework we have provided here to more quantitatively rigorous simulation models and experimental evidence.

\begin{abstract}
Acknowledgements This study was funded by a NSF Graduate Research Fellowship and the USDA National Institute of Food and Agriculture (Grant Number 2014-6701921716). Partial funding was provided by the New Hampshire Agricultural Experiment Station. This is Scientific Contribution Number 2781. This work was supported by the USDA National Institute of Food and Agriculture Hatch Project 1007001. We thank the editor and two anonymous reviewers for their valuable and constructive feedback.
\end{abstract}

\section{Compliance with ethical standards}

Conflict of interest The authors declare that they have no conflict of interest.

Open Access This article is distributed under the terms of the Creative Commons Attribution 4.0 International License (http:// creativecommons.org/licenses/by/4.0/), which permits unrestricted use, distribution, and reproduction in any medium, provided you give appropriate credit to the original author(s) and the source, provide a link to the Creative Commons license, and indicate if changes were made.

\section{References}

Abril A, Caucas V, Bucher E (2001) Reliability of the in situ incubation methods used to assess nitrogen mineralization: a microbiological perspective. Appl Soil Ecol 17:125-130. https://doi.org/10.1016/S0929-1393(01)00128-7

Accoe F, Boeckx P, Busschaert J et al (2004) Gross N transformation rates and net $\mathrm{N}$ mineralisation rates related to the $\mathrm{C}$ and $\mathrm{N}$ contents of soil organic matter fractions in grassland soils of different age. Soil Biol Biochem 36:2075-2087. https://doi.org/10.1016/j.soilbio.2004.06. 006

Allison SD (2006) Brown ground: a soil carbon analogue for the green world hypothesis? Am Nat 167:619-627. https://doi. org/10.1086/503443

Arshad MA, Franzluebbers AJ, Azooz RH (2004) Surface-soil structural properties under grass and cereal production on a Mollic Cyroboralf in Canada. Soil Tillage Res 77:15-23. https://doi.org/10.1016/j.still.2003.10.004

Avena M, Koopal L (1998) Desorption of humic acids from an iron oxide surface. Environ Sci Technol 32:2572-2577

Bailey VL, Smith AP, Tfaily M et al (2017) Differences in soluble organic carbon chemistry in pore waters sampled from different pore size domains. Soil Biol Biochem 107:133-143. https://doi.org/10.1016/J.SOILBIO.2016. 11.025

Bardgett RD, Streeter TC, Bol R (2003) Soil microbes compete effectively with plants for organic-nitrogen inputs to temperate grasslands. Ecology 84:1277-1287. https://doi.org/ 10.1890/0012-9658(2003)084

Bending GD, Read DJ (1996) Nitrogen mobilization from protein-polyphenol complex by ericoid and ectomyccorhizal fungi. Soil Biol Biochem 28:1603-1612

Bending GD, Turner MK, Jones JE (2002) Interactions between crop residue and soil organic matter quality and the functional diversity of soil microbial communities. Soil Biol Biochem 34:1073-1082. https://doi.org/10.1016/S00380717(02)00040-8

Bernal S, Hedin LO, Likens GE et al (2012) Complex response of the forest nitrogen cycle to climate change. Proc Natl Acad Sci USA 109:3406-3411. https://doi.org/10.1073/ pnas. 1121448109

Biederbeck VO, Janzen HH, Campbell CA, Zentner RP (1994) Labile soil organic matter as influenced by cropping practices in an arid environment. Soil Biol Biochem 26:1647-1656. https://doi.org/10.1016/00380717(94)90317-4

Bingeman CW, Varner JE, Martin WP (1953) The effect of the addition of organic materials on the decomposition of an organic soil. Soil Sci Soc Am J 17:34-38. https://doi.org/ 10.2136/sssaj1953.03615995001700010008x

Bingham AH, Cotrufo MF (2016) Organic nitrogen storage in mineral soil: implications for policy and management. Sci Total Environ 551-552:116-126. https://doi.org/10.1016/j. scitotenv.2016.02.020 
Bonneville S, Smits M, Brown A et al (2009) Plant-driven fungal weathering: early stages of mineral alteration at the nanometer scale. Geology 37:615-618. https://doi.org/10. 1130/G25699A.1

Bowsher AW, Ali R, Harding SA et al (2015) Analysis of wild sunflower (Helianthus annuus L.) root exudates using gas chromatography-mass spectrometry. J Plant Nutr Soil Sci 178:776-786. https://doi.org/10.1002/jpln.201400521

Bronson KF, Zobeck TM, Chua TT et al (2004) Carbon and nitrogen pools of southern high plains cropland and grassland soils. Soil Sci Soc Am J 68:1695-1704

Brzostek ER, Greco A, Drake JE, Finzi AC (2013) Root carbon inputs to the rhizosphere stimulate extracellular enzyme activity and increase nitrogen availability in temperate forest soils. Biogeochemistry 115:65-76. https://doi.org/ 10.1007/s10533-012-9818-9

Burford EP, Hillier S, Gadd GM et al (2006) Biomineralization of fungal hyphae with calcite $(\mathrm{CaCO} 3)$ and calcium oxalate mono-and dihydrate in carboniferous limestone microcosms for the kelso limestone samples. Geomicrobiol J 23:599-611. https://doi.org/10.1080/01490450600964375

Call HP, Mücke I (1997) History, overview and applications of mediated lignolytic systems, especially laccase-mediatorsystems (Lignozym ${ }^{\circledR}$-process). J Biotechnol 53:163-202. https://doi.org/10.1016/S0168-1656(97)01683-0

Calvaruso C, Mareschal L, Turpault M-P, Leclerc E (2009) Rapid clay weathering in the rhizosphere of norway spruce and oak in an acid forest ecosystem. Soil Sci Soc Am J 73:331. https://doi.org/10.2136/sssaj2007.0400

Carney KM, Hungate BA, Drake BG, Megonigal JP (2007) Altered soil microbial community at elevated $\mathrm{CO} 2$ leads to loss of soil carbon. Proc Natl Acad Sci USA 104:4990-4995

Cavagnaro TR, Barrios-Masias FH, Jackson LE (2012) Arbuscular mycorrhizas and their role in plant growth, nitrogen interception and soil gas efflux in an organic production system. Plant Soil 353:181-194. https://doi.org/10.1007/ s11104-011-1021-6

Chen B, Liu E, Tian Q et al (2014) Soil nitrogen dynamics and crop residues. A review. Agron Sustain Dev 34:429-442. https://doi.org/10.1007/s13593-014-0207-8\&gt

Chen J, Hofmockel KS, Hobbie EA (2016) Isotopic analysis of sporocarp protein and structural material improves resolution of fungal carbon sources. Front Microbiol 7:1994. https://doi.org/10.3389/fmicb.2016.01994

Ciadamidaro L, Madejón P, Madejón E (2014) Soil chemical and biochemical properties under Populus alba growing: three years study in trace element contaminated soils. Appl Soil Ecol 73:26-33. https://doi.org/10.1016/j.apsoil.2013. 08.003

Clarholm M, Skyllberg U, Rosling A (2015) Organic acid induced release of nutrients from metal-stabilized soil organic matter-the unbutton model. Soil Biol Biochem 84:168-176. https://doi.org/10.1016/j.soilbio.2015.02.019

Courty P-E, Buée M, Diedhiou AG et al (2010) The role of ectomycorrhizal communities in forest ecosystem processes: new perspectives and emerging concepts. Soil Biol Biochem 42:679-698. https://doi.org/10.1016/J.SOILBIO. 2009.12.006
Craine JM, Morrow C, Fierer N (2007) Microbial nitrogen limitation increases decomposition. Ecology 88:2105-2113. https://doi.org/10.1890/06-1847.1

Darrouzet-Nardi A, Weintraub MN (2014) Evidence for spatially inaccessible labile $\mathrm{N}$ from a comparison of soil core extractions and soil pore water lysimetry. Soil Biol Biochem 73:22-32. https://doi.org/10.1016/j.soilbio.2014.02. 010

Dashman T, Stotzky G (1986) Microbial utilization of amino acids and a peptide bound on homoionic montmorillonite and kaolinite. Soil Biol Biochem 18:5-14. https://doi.org/ 10.1016/0038-0717(86)90096-9

Dashtban M, Schraft H, Syed TA, Qin W (2010) Fungal biodegradation and enzymatic modification of lignin. Int $\mathrm{J}$ Biochem Mol Biol 1:36-50

de Graaff MA, Van Kessel C, Six J (2009) Rhizodepositioninduced decomposition increases $\mathrm{N}$ availability to wild and cultivated wheat genotypes under elevated CO2. Soil Biol Biochem 41:1094-1103. https://doi.org/10.1016/j.soilbio. 2009.02.015

DeAngelis KM, Lindow SE, Firestone MK (2008) Bacterial quorum sensing and nitrogen cycling in rhizosphere soil. FEMS Microbiol Ecol 66:197-207

Delgado-Baquerizo M, Gallardo A (2011) Depolymerization and mineralization rates at 12 Mediterranean sites with varying soil $\mathrm{N}$ availability. A test for the Schimel and Bennett model. Soil Biol Biochem 43:693-696. https://doi. org/10.1016/J.SOILBIO.2010.11.030

Denef K, Del Galdo I, Venturi A, Cotrufo MF (2013) Assessment of soil $\mathrm{C}$ and $\mathrm{N}$ stocks and fractions across 11 European soils under varying land uses. Open J Soil Sci 3:297-313

Dijkstra FA, Bader NE, Johnson DW, Cheng W (2009) Does accelerated soil organic matter decomposition in the presence of plants increase plant $\mathrm{N}$ availability? Soil Biol Biochem 41:1080-1087. https://doi.org/10.1016/j.soilbio. 2009.02.013

Dippold M, Biryukov M, Kuzyakov Y (2014) Sorption affects amino acid pathways in soil: implications from positionspecific labeling of alanine. Soil Biol Biochem 72:180-192. https://doi.org/10.1016/j.soilbio.2014.01.015

Dorodnikov M, Kuzyakov Y, Fangmeier A, Wiesenberg GLB (2011) $\mathrm{C}$ and $\mathrm{N}$ in soil organic matter density fractions under elevated atmospheric CO2: turnover vs. stabilization. Soil Biol Biochem 43:579-589. https://doi.org/10. 1016/j.soilbio.2010.11.026

Drake JE, Gallet-Budynek A, Hofmockel KS et al (2011) Increases in the flux of carbon belowground stimulate nitrogen uptake and sustain the long-term enhancement of forest productivity under elevated $\mathrm{CO}_{2}$. Ecol Lett 14:349-357. https://doi.org/10.1111/j.1461-0248.2011. 01593.x

Fabrizzi KP, Morón A, García FO (2003) Soil carbon and nitrogen organic fractions in degraded vs. non-degraded mollisols in Argentina. Soil Sci Soc Am J 67:1831-1841. https://doi.org/10.2136/sssaj2003.1831

Finzi AC, Abramoff RZ, Spiller KS et al (2015) Rhizosphere processes are quantitatively important components of terrestrial carbon and nutrient cycles. Glob Change Biol 21:2082-2094. https://doi.org/10.1111/gcb.12816 
Fischer H, Ingwersen J, Kuzyakov Y (2010) Microbial uptake of low-molecular-weight organic substances out-competes sorption in soil. Eur J Soil Sci 61:504-513. https://doi.org/ 10.1111/j.1365-2389.2010.01244.x

Fog K (1988) The effect of added nitrogen on the rate of decomposition of organic matter. Biol Rev 63:433-462. https://doi.org/10.1111/j.1469-185X.1988.tb00725.x

Fontaine S, Henault C, Aamor A et al (2011) Fungi mediate long term sequestration of carbon and nitrogen in soil through their priming effect. Soil Biol Biochem 43:86-96. https:// doi.org/10.1016/j.soilbio.2010.09.017

Fornara D, Bardgett R, Steinbeiss S et al (2011) Plant effects on soil $\mathrm{N}$ mineralization are mediated by the composition of multiple soil organic fractions. Ecol Res 26:201-208. https://doi.org/10.1007/s11284-010-0777-0

Furrer G, Stumm W (1986) The coordination chemistry of weathering: I. Dissolution kinetics of 6-A12O3 and $\mathrm{BeO}$. Geochim Cosmochim Acta 50:1847-1860

Gadd G (2010) Metals, minerals and microbes: geomicrobiology and bioremediation. Microbiology 156:609-643. https://doi.org/10.1099/mic.0.037143-0

Gao J, Jansen B, Cerli C et al (2017) Competition and surface conditioning alter the adsorption of phenolic and amino acids on soil minerals. Eur J Soil Sci 68:667-677. https:// doi.org/10.1111/ejss.12459

Geyer KM, Kyker-Snowman E, Grandy AS, Frey SD (2016) Microbial carbon use efficiency: accounting for population, community, and ecosystem-scale controls over the fate of metabolized organic matter. Biogeochemistry 127:173-188. https://doi.org/10.1007/s10533-016-0191-y

Gianfreda L, Bollag J-M (1994) Effect of soils on the behavior of immobilized enzymes. Soil Sci Soc Am J 58:1672. https://doi.org/10.2136/sssaj1994. 03615995005800060014x

Golubev SV, Bauer A, Pokrovsky OS (2006) Effect of pH and organic ligands on the kinetics of smectite dissolution at 25 ${ }^{\circ} \mathrm{C}$. Geochim Cosmochim Acta 70:4436-4451. https://doi. org/10.1016/j.gca.2006.06.1557

Gosling P, Parsons N, Bending GD (2013) What are the primary factors controlling the light fraction and particulate soil organic matter content of agricultural soils? Biol Fertil Soils 49:1001-1014. https://doi.org/10.1007/s00374-0130791-9

Grandy AS, Neff JC (2008) Molecular C dynamics downstream: the biochemical decomposition sequence and its impact on soil organic matter structure and function. Sci Total Environ 404:297-307. https://doi.org/10.1016/j.scitotenv. 2007.11.013

Grandy AS, Robertson GP (2007) Land-use intensity effects on soil organic carbon accumulation rates and mechanisms. Ecosystems 10:59-74. https://doi.org/10.1007/s10021006-9010-y

Grandy AS, Sinsabaugh RL, Neff JC et al (2008) Nitrogen deposition effects on soil organic matter chemistry are linked to variation in enzymes, ecosystems and size fractions. Biogeochemistry 91:37-49

Haddix ML, Paul EA, Cotrufo MF (2016) Dual, differential isotope labeling shows the preferential movement of labile plant constituents into mineral-bonded soil organic matter. Glob Change Biol 22:2301-2312. https://doi.org/10.1111/ gcb. 13237
Halvorson JJ, Schmidt MA, Hagerman AE et al (2016) Reduction of soluble nitrogen and mobilization of plant nutrients in soils from U.S northern Great Plains agroecosystems by phenolic compounds. Soil Biol Biochem 94:211-221. https://doi.org/10.1016/j.soilbio.2015.11.022

Hart SC, Stark JM, Davidson EA, Firestone MK (1994) Nitrogen mineralization, immobilization, and nitrification. In: Methods of soil analysis: Part 2-microbiological and biochemical properties. Soil Science Society of America, pp 985-1018

Haynes RJ (2005) Labile organic matter fractions as central components of the quality of agricultural soils: an overview. Adv Agron 85:221-268. https://doi.org/10.1016/ S0065-2113(04)85005-3

Herman DJ, Johnson KK, Jaeger CH et al (2006) Root influence on nitrogen mineralization and nitrification in Avena barbata rhizosphere soil. Soil Sci Soc Am J 70:1504-1511. https://doi.org/10.2136/sssaj2005.0113

Herrmann AM, Clode PL, Fletcher IR et al (2007) A novel method for the study of the biophysical interface in soils using nano-scale secondary ion mass spectrometry. Rapid Commun Mass Spectrom 21:29-34. https://doi.org/10. $1002 / \mathrm{rcm} .2811$

Hinsinger P (2001) Bioavailability of soil inorganic P in the rhizosphere as affected by root-induced chemical changes : a review. Plant Soil 237:173-195

Hobbie EA, Ouimette AP, Schuur EAG et al (2012) Radiocarbon evidence for the mining of organic nitrogen from soil by mycorrhizal fungi. Biogeochemistry 114:381-389. https://doi.org/10.1007/s10533-012-9779-z

Hodge A, Stewart J, Robinson D et al (2000) Competition between roots and soil micro-organisms for nutrients from nitrogen-rich patches of varying complexity. J Ecol 88:150-164. https://doi.org/10.1046/j.1365-2745.2000. 00434.x

Hofmockel KS, Zak DR, Moran KK, Jastrow JD (2011) Changes in forest soil organic matter pools after a decade of elevated CO2 and O3. Soil Biol Biochem 43:1518-1527. https://doi.org/10.1016/j.soilbio.2011.03.030

Högberg P, Näsholm T, Franklin O, Högberg MN (2017) Tamm review: on the nature of the nitrogen limitation to plant growth in Fennoscandian boreal forests. For Ecol Manage 403:161-185. https://doi.org/10.1016/J.FORECO.2017. 04.045

Houlton BZ, Morford SL, Dahlgren RA (2018) Convergent evidence for widespread rock nitrogen sources in Earth's surface environment. Science 360:58-62. https://doi.org/ 10.1126/science.aan4399

Huo C, Luo Y, Cheng W (2017) Rhizosphere priming effect: a meta-analysis. Soil Biol Biochem 111:78-84. https://doi. org/10.1016/j.soilbio.2017.04.003

Jones DL (1998) Organic acids in the rhizosphere-a critical review. Plant Soil 205:25-44. https://doi.org/10.1023/A: 1004356007312

Kaiser K, Kalbitz K (2012) Cycling downwards-dissolved organic matter in soils. Soil Biol Biochem 52:29-32. https://doi.org/10.1016/j.soilbio.2012.04.002

Kaiser K, Zech W (2000) Sorption of dissolved organic nitrogen by acid subsoil horizons and individual mineral phases. Eur J Soil Sci 51:403-411. https://doi.org/10.1046/j.13652389.2000.00320.x 
Keiluweit M, Bougoure JJ, Nico PS et al (2015) Mineral protection of soil carbon counteracted by root exudates. Nat Clim Change 5:588-595. https://doi.org/10.1038/ nclimate2580

Kieloaho A-J, Pihlatie M, Dominguez Carrasco M et al (2016) Stimulation of soil organic nitrogen pool: the effect of plant and soil organic matter degrading enzymes. Soil Biol Biochem 96:97-106. https://doi.org/10.1016/j.soilbio. 2016.01.013

Kim HJ, Suma Y, Lee SH et al (2012) Immobilization of horseradish peroxidase onto clay minerals using soil organic matter for phenol removal. J Mol Catal B Enzym 83:8-15. https://doi.org/10.1016/j.molcatb.2012.06.012

Kleber M, Mikutta R, Torn MS, Jahn R (2005) Poorly crystalline mineral phases protect organic matter in acid subsoil horizons. Eur J Soil Sci 56:717-725. https://doi.org/10. 1111/j.1365-2389.2005.00706.x

Kleber M, Sollins P, Sutton R (2007) A conceptual model of organo-mineral interactions in soils: self-assembly of organic molecular fragments into zonal structures on mineral surfaces. Biogeochemistry 85:9-24. https://doi. org/10.1007/s10533-007-9103-5

Kleber M, Eusterhues K, Keiluweit M et al (2015) Mineralorganic associations: formation, properties, and relevance in soil environments. Adv Agron 130:1-140. https://doi. org/10.1016/bs.agron.2014.10.005

Knicker H (2011) Soil organic N-an under-rated player for C sequestration in soils? Soil Biol Biochem 43:1118-1129. https://doi.org/10.1016/j.soilbio.2011.02.020

Koele N, Dickie IA, Blum JD et al (2014) Ecological significance of mineral weathering in ectomycorrhizal and arbuscular mycorrhizal ecosystems from a field-based comparison. Soil Biol Biochem 69:63-70. https://doi.org/ 10.1016/J.SOILBIO.2013.10.041

Kopittke PM, Hernandez-Soriano MC, Dalal RC et al (2017) Nitrogen-rich microbial products provide new organomineral associations for the stabilization of soil organic matter. Glob Change Biol. https://doi.org/10.1111/gcb. 14009

Koranda M, Schnecker J, Kaiser C et al (2011) Microbial processes and community composition in the rhizosphere of European beech-the influence of plant $\mathrm{C}$ exudates. Soil Biol Biochem 43:551-558. https://doi.org/10.1016/j. soilbio.2010.11.022

Kuzyakov Y (2010) Priming effects: interactions between living and dead organic matter. Soil Biol Biochem 42:1363-1371. https://doi.org/10.1016/j.soilbio.2010.04. 003

Kuzyakov Y, Xu X (2013) Competition between roots and microorganisms for nitrogen: mechanisms and ecological relevance. New Phytol 198:656-669. https://doi.org/10. 1111/nph.12235

Kuzyakov Y, Friedel JK, Stahr K (2000) Review of mechanisms and quanti ${ }^{\circledR}$ cation of priming effects. Soil Biol Biochem 32:747-758

Lagomarsino A, Grego S, Kandeler E (2012) Soil organic carbon distribution drives microbial activity and functional diversity in particle and aggregate-size fractions. Pedobiologia (Jena) 55:101-110. https://doi.org/10.1016/j. pedobi.2011.12.002
Lajtha K, Crow SE, Yano Y et al (2005) Detrital controls on soil solution $\mathrm{N}$ and dissolved organic matter in soils: a field experiment. Biogeochemistry 76:261-281. https://doi.org/ 10.1007/s10533-005-5071-9

Lajtha K, Bowden RD, Nadelhoffer K (2014) Litter and root manipulations provide insights into soil organic matter dynamics and stability. Soil Sci Soc Am J 78:S261. https:// doi.org/10.2136/sssaj2013.08.0370nafsc

Lambert JF (2008) Adsorption and polymerization of amino acids on mineral surfaces: a review. Orig Life Evol Biosph 38:211-242

Leinemann T, Preusser S, Mikutta R et al (2018) Multiple exchange processes on mineral surfaces control the transport of dissolved organic matter through soil profiles. Soil Biol Biochem 118:79-90. https://doi.org/10.1016/J. SOILBIO.2017.12.006

Liebig MA, Tanaka DL, Wienhold BJ (2004) Tillage and cropping effects on soil quality indicators in the northern Great Plains. Soil Tillage Res 78:131-141. https://doi.org/ 10.1016/j.still.2004.02.002

Liu J, You L, Amini M et al (2010) A high-resolution assessment on global nitrogen flows in cropland. Proc Natl Acad Sci USA 107:8035-8040. https://doi.org/10.1073/pnas. 0913658107

Loeppmann S, Blagodatskaya E, Pausch J, Kuzyakov Y (2016) Enzyme properties down the soil profile-a matter of substrate quality in rhizosphere and detritusphere. Soil Biol Biochem 103:274-283. https://doi.org/10.1016/j.soilbio. 2016.08.023

Lu H, He H, Zhao J et al (2013) Dynamics of fertilizer-derived organic nitrogen fractions in an arable soil during a growing season. Plant Soil 373:595-607. https://doi.org/ 10.1007/s11104-013-1824-8

Luce MS, Whalen JK, Ziadi N, Zebarth BJ (2011) Nitrogen dynamics and indices to predict soil nitrogen supply in humid temperate soils. Adv Agron 112:55-102. https://doi. org/10.1016/B978-0-12-385538-1.00002-0

Mareschal L, Turpault MP, Bonnaud P, Ranger J (2013) Relationship between the weathering of clay minerals and the nitrification rate: a rapid tree species effect. Biogeochemistry 112:293-309. https://doi.org/10.1007/s10533-0129725-0

Marin-Spiotta E, Silver WL, Swanston CW, Ostertag R (2009) Soil organic matter dynamics during 80 years of reforestation of tropical pastures. Glob Change Biol 15:1584-1597. https://doi.org/10.1111/j.1365-2486.2008. 01805.x

McFarlane KJ, Torn MS, Hanson PJ et al (2013) Comparison of soil organic matter dynamics at five temperate deciduous forests with physical fractionation and radiocarbon measurements. Biogeochemistry 112:457-476. https://doi.org/ 10.1007/s10533-012-9740-1

Meier IC, Finzi AC, Phillips RP (2017) Root exudates increase $\mathrm{N}$ availability by stimulating microbial turnover of fastcycling N pools. Soil Biol Biochem 106:119-128. https:// doi.org/10.1016/j.soilbio.2016.12.004

Mendham D, Heagney E, Corbeels M et al (2004) Soil particulate organic matter effects on nitrogen availability after afforestation with Eucalyptus globulus. Soil Biol Biochem 36:1067-1074. https://doi.org/10.1016/J.SOILBIO.2004. 02.018 
Mikutta R, Kaiser K, Dörr N et al (2010) Mineralogical impact on organic nitrogen across a long-term soil chronosequence (0.3-4100 kyr). Geochim Cosmochim Acta 74:2142-2164. https://doi.org/10.1016/j.gca.2010.01.006

Miltner A, Bombach P, Schmidt-Brucken B, Kastner M (2012) SOM genesis: microbial biomass as a significant source. Biogeochemistry 111:41-55

Ming Shi X, Gang Li X, Jun Long R et al (2010) Dynamics of soil organic carbon and nitrogen associated with physically separated fractions in a grassland-cultivation sequence in the Qinghai-Tibetan plateau. Biol Fertil Soils 46:103-111. https://doi.org/10.1007/s00374-009-0414-7

Mobley ML, Lajtha K, Kramer MG et al (2015) Surficial gains and subsoil losses of soil carbon and nitrogen during secondary forest development. Glob Change Biol 21:986-996. https://doi.org/10.1111/gcb.12715

Monaco S, Sacco D, Borda T, Grignani C (2010) Field measurement of net nitrogen mineralization of manured soil cropped to maize. Biol Fertil Soils 46:179-184. https://doi. org/10.1007/s00374-009-0412-9

Monaghan R, Barraclough D (1997) Contributions to N mineralization from soil macroorganic matter fractions incorporated into two field soils. Soil Biol Biochem 29:1215-1223

Mooshammer M, Wanek W, Hämmerle I et al (2014) Adjustment of microbial nitrogen use efficiency to carbon:nitrogen imbalances regulates soil nitrogen cycling. Nat Commun 5:3694. https://doi.org/10.1038/ncomms4694

Murphy CJ, Baggs EM, Morley N et al (2015) Rhizosphere priming can promote mobilisation of N-rich compounds from soil organic matter. Soil Biol Biochem 81:236-243. https://doi.org/10.1016/j.soilbio.2014.11.027

Niu S, Ee A, Classen T et al (2016) Global patterns and substrate-based mechanisms of the terrestrial nitrogen cycle. Ecol Lett 19:697-709. https://doi.org/10.1111/ele.12591

Oburger E, Kirk GJD, Wenzel WW et al (2009) Interactive effects of organic acids in the rhizosphere. Soil Biol Biochem 41:449-457. https://doi.org/10.1016/j.soilbio.2008. 10.034

Oburger E, Dell'mour M, Hann S et al (2013) Evaluation of a novel tool for sampling root exudates from soil-grown plants compared to conventional techniques. Environ Exp Bot 87:235-247. https://doi.org/10.1016/J.ENVEXPBOT. 2012.11.007

Osterholz WR, Rinot O, Liebman M, Castellano MJ (2016) Can mineralization of soil organic nitrogen meet maize nitrogen demand? Plant Soil. https://doi.org/10.1007/s11104-016$3137-1$

Pan F, Liang Y, Zhang W et al (2016) Enhanced nitrogen availability in karst ecosystems by oxalic acid release in the rhizosphere. Front Plant Sci 7:687. https://doi.org/10.3389/ fpls.2016.00687

Paola A, Pierre B, Vincenza C et al (2016) Short term clay mineral release and re-capture of potassium in a Zea mays field experiment. Geoderma 264:54-60. https://doi.org/10. 1016/j.geoderma.2015.10.005

Parfitt RL, Salt GJ (2001) Carbon and nitrogen mineralisation in sand, silt, and clay fractions of soils under maize and pasture. Aust J Soil Res Aust J Soil Res 39:361-371. https://doi.org/10.1071/SR00028
Partavian A, Mikkelsen TN, Vestergård M (2015) Plants increase laccase activity in soil with long-term elevated $\mathrm{CO}_{2}$ legacy. Eur J Soil Biol 70:97-103. https://doi.org/10. 1016/j.ejsobi.2015.08.002

Paul EA (2016) The nature and dynamics of soil organic matter: plant inputs, microbial transformations, and organic matter stabilization. Soil Biol Biochem 98:109-126. https://doi. org/10.1016/j.soilbio.2016.04.001

Pellitier PT, Zak DR (2018) Ectomycorrhizal fungi and the enzymatic liberation of nitrogen from soil organic matter: why evolutionary history matters. New Phytol 217:68-73. https://doi.org/10.1111/nph.14598

Pett-Ridge J, Firestone MK (2017) Using stable isotopes to explore root-microbe-mineral interactions in soil. Rhizosphere 3:244-253. https://doi.org/10.1016/j.rhisph.2017. 04.016

Phillips RP, Finzi AC, Bernhardt ES (2011) Enhanced root exudation induces microbial feedbacks to $\mathrm{N}$ cycling in a pine forest under long-term $\mathrm{CO}_{2}$ fumigation. Ecol Lett 14:187-194. https://doi.org/10.1111/j.1461-0248.2010. 01570.x

Phillips RP, Meier IC, Bernhardt ES et al (2012) Roots and fungi accelerate carbon and nitrogen cycling in forests exposed to elevated $\mathrm{CO}_{2}$. Ecol Lett 15:1042-1049. https://doi.org/ 10.1111/j.1461-0248.2012.01827.x

Quiquampoix H, Staunton S, Baron M-H, Ratcliffe RG (1993) Interpretation of the $\mathrm{pH}$ dependence of protein adsorption on clay mineral surfaces and its relevance to the understanding of extracellular enzyme activity in soil. Colloids Surf A Physicochem Eng Asp 75:85-93. https://doi.org/10. 1016/0927-7757(93)80419-F

Rashad M, Dultz S, Guggenberger G (2010) Dissolved organic matter release and retention in an alkaline soil from the Nile River Delta in relation to surface charge and electrolyte type. Geoderma 158:385-391. https://doi.org/10. 1016/j.geoderma.2010.06.007

Rasmussen C, Southard RJ, Horwath WR (2007) Soil mineralogy affects conifer forest soil carbon source utilization and microbial priming. Soil Sci Soc Am J 71:1141. https://doi. org/10.2136/sssaj2006.0375

Reardon PN, Chacon SS, Walter ED et al (2016) Abiotic protein fragmentation by manganese oxide: implications for a mechanism to supply soil biota with oligopeptides. Environ Sci Technol 50:3486-3493. https://doi.org/10.1021/acs. est.5b04622

Remiszewski KA, Bryce JG, Fahnestock MF et al (2016) Elemental and isotopic perspectives on the impact of arbuscular mycorrhizal and ectomycorrhizal fungi on mineral weathering across imposed geologic gradients. Chem Geol 445:164-171. https://doi.org/10.1016/J.CHEMGEO.2016. 05.005

Reynolds HL, Packer A, Bever JD, Clay K (2003) Grassroots ecology: plant-microbe-soil interactions as drivers of plant community structure and dynamics. Ecology 84:2281-2291

Richardson AE, Barea J-M, McNeill AM, Prigent-Combaret C (2009) Acquisition of phosphorus and nitrogen in the rhizosphere and plant growth promotion by microorganisms. Plant Soil 321:305-339. https://doi.org/10.1007/s11104009-9895-2 
Richter DD, Markewitz D, Trumbore SE, Wells CG (1999) Rapid accumulation and turnover of soil carbon in a reestablishing forest. Nature 400:56-58. https://doi.org/10. $1038 / 21867$

Rillig MC, Mummey DL (2006) Mycorrhizas and soil structure. New Phytol 171:41-53. https://doi.org/10.1111/j.14698137.2006.01750.x

Rinkes ZL, Bertrand I, Amin BAZ et al (2016) Nitrogen alters microbial enzyme dynamics but not lignin chemistry during maize decomposition. Biogeochemistry 128:171-186. https://doi.org/10.1007/s10533-016-0201-0

Roberts P, Jones DL (2012) Microbial and plant uptake of free amino sugars in grassland soils. Soil Biol Biochem 49:139-149. https://doi.org/10.1016/j.soilbio.2012.02.014

Rousk K, Michelsen A, Rousk J (2016) Microbial control of soil organic matter mineralisation responses to labile carbon in subarctic climate change treatments. Glob Change Biol 22:4150-4161. https://doi.org/10.1111/gcb.13296

Sanderman J, Baldock JA, Amundson R (2008) Dissolved organic carbon chemistry and dynamics in contrasting forest and grassland soils. Biogeochemistry 89:181-198. https://doi.org/10.1007/s10533-008-9211-x

Schimel JP, Bennett J (2004) Nitrogen mineralization: challenges of a changing paradigm. Ecology 85:591-602. https://doi.org/10.1890/03-8002

Schimel J, Becerra CA, Blankinship J (2017) Estimating decay dynamics for enzyme activities in soils from different ecosystems. Soil Biol Biochem 114:5-11. https://doi.org/ 10.1016/j.soilbio.2017.06.023

Schmidt MWI, Torn MS, Abiven S et al (2011) Persistence of soil organic matter as an ecosystem property. Nature 478:49-56. https://doi.org/10.1038/nature10386

Schnecker J, Borken W, Schindlbacher A, Wanek W (2016) Little effects on soil organic matter chemistry of density fractions after seven years of forest soil warming. Soil Biol Biochem 103:300-307. https://doi.org/10.1016/J. SOILBIO.2016.09.003

Schomberg HH, Wietholter S, Griffin TS et al (2009) Assessing indices for predicting potential nitrogen mineralization in soils under different management systems. Soil Sci Soc Am J 73:1575. https://doi.org/10.2136/sssaj2008.0303

Scott EE, Rothstein DE (2014) The dynamic exchange of dissolved organic matter percolating through six diverse soils. Soil Biol Biochem 69:83-92. https://doi.org/10.1016/j. soilbio.2013.10.052

Sharma SB, Sayyed RZ, Trivedi MH et al (2013) Phosphate solubilizing microbes: sustainable approach for managing phosphorus deficiency in agricultural soils. Springerplus 2:587. https://doi.org/10.1186/2193-1801-2-587

Shukla G, Varma A (2011) Soil Enzymology. Springer, Berlin

Singh M, Sarkar B, Biswas B et al (2016) Adsorption-desorption behavior of dissolved organic carbon by soil clay fractions of varying mineralogy. Geoderma 280:47-56. https://doi. org/10.1016/j.geoderma.2016.06.005

Singh M, Sarkar B, Sarkar S, et al (2017) Stabilization of soil organic carbon as influenced by clay mineralogy. In: Advances in Agronomy

Sinsabaugh RL (2009) Phenol oxidase, peroxidase and organic matter dynamics of soil. Soil Biol Biochem 42:391-404. https://doi.org/10.1016/j.soilbio.2009.10.014
Sinsabaugh RL, Manzoni S, Moorhead DL, Richter A (2013) Carbon use efficiency of microbial communities: stoichiometry, methodology and modelling. Ecol Lett 16:930-939. https://doi.org/10.1111/ele.12113

Sinsabaugh RL, Turner BL, Talbot JM et al (2016) Stoichiometry of microbial carbon use efficiency in soils. Ecol Monogr 86:172-189. https://doi.org/10.1890/15-2110.1

Smith AP, Bond-Lamberty B, Benscoter BW et al (2017) Shifts in pore connectivity from precipitation versus groundwater rewetting increases soil carbon loss after drought. Nat Commun 8:1335. https://doi.org/10.1038/s41467-01701320-x

Sollins P, Spycher G, Glassman CA (1984) Net nitrogen mineralization from light- and heavy-fraction forest soil organic matter. Soil Biol Biochem 16:31-37. https://doi. org/10.1016/0038-0717(84)90122-6

Sollins P, Swanston C, Kleber M et al (2006) Organic C and N stabilization in a forest soil: evidence from sequential density fractionation. Soil Biol Biochem 38:3313-3324. https://doi.org/10.1016/j.soilbio.2006.04.014

Swenson TL, Bowen BP, Nico PS, Northen TR (2015) Competitive sorption of microbial metabolites on an iron oxide mineral. Soil Biol Biochem 90:34-41. https://doi.org/10. 1016/j.soilbio.2015.07.022

Talbot JM, Allison SD, Treseder KK (2008) Decomposers in disguise: mycorrhizal fungi as regulators of soil $\mathrm{C}$ dynamics in ecosystems under global change. Funct Ecol 22:955-963. https://doi.org/10.1111/j.1365-2435.2008. 01402.x

Thaysen EM, Reinsch S, Larsen KS, Ambus P (2017) Decrease in heathland soil labile organic carbon under future atmospheric and climatic conditions. Biogeochemistry 133:17-36. https://doi.org/10.1007/s10533-017-0303-3

Theng BKG (1974) The Chemistry of Clay-Organic Reactions. Wiley, New York

Tian L, Dell E, Shi W (2010) Chemical composition of dissolved organic matter in agroecosystems: correlations with soil enzyme activity and carbon and nitrogen mineralization. Appl Soil Ecol 46:426-435. https://doi.org/10.1016/J. APSOIL.2010.09.007

Tietjen T, Wetzel RG (2003) Extracellular enzyme-clay mineral complexes: enzyme adsorption, alteration of enzyme activity, and protection from photodegradation. Aquat Ecol 37:331-339. https://doi.org/10.1023/B:AECO. $0000007044.52801 .6 \mathrm{~b}$

Toosi ER, Doane TA, Horwath WR (2012) Abiotic solubilization of soil organic matter, a less-seen aspect of dissolved organic matter production. Soil Biol Biochem 50:12-21. https://doi.org/10.1016/j.soilbio.2012.02.033

Turner S, Meyer-Stüve S, Schippers A et al (2017) Microbial utilization of mineral-associated nitrogen in soils. Soil Biol Biochem 104:185-196. https://doi.org/10.1016/j.soilbio. 2016.10.010

Uroz S, Kelly LC, Turpault M-P et al (2015) The mineralosphere concept: mineralogical control of the distribution and function of mineral-associated bacterial communities. Trends Microbiol 23:751-762. https://doi.org/10.1016/j. tim.2015.10.004

Van Breeman N, Finlay R, Lundström U et al (2000) Mycorrhizal weathering: a true case of mineral plant nutrition? Biogeochemistry 49:53-67 
van Groenigen JW, Huygens D, Boeckx P et al (2015) The soil N cycle: new insights and key challenges. Soil 1:235-256. https://doi.org/10.5194/soil-1-235-2015

Violante A, Caporale AG (2015) Biogeochemical processes at soil-root interface. J Soil Sci Plant Nutr 15:422-448

Wade J, Waterhouse H, Roche LM, Horwath WR (2018) Structural equation modeling reveals iron (hydr)oxides as a strong mediator of $\mathrm{N}$ mineralization in California agricultural soils. Geoderma 315:120-129. https://doi.org/10. 1016/j.geoderma.2017.11.039

Wander M (2004) Soil organic matter fractions and their relevance to soil function. In: Magdoff $F$, Weil $\mathrm{R}$ (eds) Advances in Agroecology. CRC Press, Boca Raton, pp 67-102

Wander MM, Bidart MG (2000) Tillage practice influences on the physical protection, bioavailability and composition of particulate organic matter. Biol Fertil Soils 32:360-367. https://doi.org/10.1007/s003740000260

Wang Z, Xu Z, Zhao J et al (2014) Effects of low-molecularweight organic acids on soil micropores and implication for organic contaminant availability. Commun Soil Sci Plant Anal 45:1120-1132. https://doi.org/10.1080/00103624. 2013.867062

Warren CR (2013) Organic N molecules in the soil solution: what is known, what is unknown and the path forwards. Plant Soil. https://doi.org/10.1007/s11104-013-1939-y

Whalen JK, Bottomley PJ, Myrold DD (2000) Carbon and nitrogen mineralization from light- and heavy-fraction additions to soil. Soil Biol Biochem 32:1345-1352. https:// doi.org/10.1016/S0038-0717(00)00040-7

Wieder WR, Grandy AS, Kallenbach CM et al (2015) Representing life in the Earth system with soil microbial functional traits in the MIMICS model. Geosci Model Dev 8:1789-1808. https://doi.org/10.5194/gmd-8-1789-2015

Wu T (2011) Can ectomycorrhizal fungi circumvent the nitrogen mineralization for plant nutrition in temperate forest ecosystems? Soil Biol Biochem 43:1109-1117. https://doi. org/10.1016/J.SOILBIO.2011.02.003

$\mathrm{Xu}$ N, Gao Y (2008) Characterization of hematite dissolution affected by oxalate coating, kinetics and $\mathrm{pH}$. Appl
Geochemistry 23:783-793. https://doi.org/10.1016/J. APGEOCHEM.2007.12.026

Yanai RD, Vadeboncoeur MA, Hamburg SP et al (2013) From missing source to missing sink: long-term changes in the nitrogen budget of a northern hardwood forest. Environ Sci Technol 47:11440-11448. https://doi.org/10.1021/ es4025723

Yin H, Li Y, Xiao J et al (2013) Enhanced root exudation stimulates soil nitrogen transformations in a subalpine coniferous forest under experimental warming. Glob Change Biol 19:2158-2167. https://doi.org/10.1111/gcb. 12161

Yu WH, Li N, Tong DS et al (2013) Adsorption of proteins and nucleic acids on clay minerals and their interactions: a review. Appl Clay Sci 80-81:443-452. https://doi.org/10. 1016/j.clay.2013.06.003

Zechmeister-Boltenstern S, Keiblinger KM, Mooshammer M et al (2015) The application of ecological stoichiometry to plant-microbial-soil organic matter transformations. Ecol Monogr 85:133-155. https://doi.org/10.1890/14-0777.1

Zhang Y, Kallay SN, Matijevic E (1985) Interactions of metal hydrous oxides with chelating agents. 7. Hematite-oxalic acid and -citric acid systems. Langmuir 1:201-206

Zhang Q, Liang G, Zhou W et al (2016) Fatty-acid profiles and enzyme activities in soil particle-size fractions under longterm fertilization. Soil Sci Soc Am J 80:97. https://doi.org/ 10.2136/sssaj2015.07.0255

Zheng W, Morris EK, Rillig MC (2014) Ectomycorrhizal fungi in association with Pinus sylvestris seedlings promote soil aggregation and soil water repellency. Soil Biol Biochem 78:326-331. https://doi.org/10.1016/J.SOILBIO.2014.07. 015

Zhu B, Gutknecht JLM, Herman DJ et al (2014) Rhizosphere priming effects on soil carbon and nitrogen mineralization. Soil Biol Biochem 76:183-192. https://doi.org/10.1016/j. soilbio.2014.04.033

Zinder B, Furrer G, Stumm W (1986) The coordination chemistry of weathering: II. Dissolution of $\mathrm{Fe}(\mathrm{III})$ oxides. Geochim Cosmochim Acta 50:1861-1869 